Ergül, C., Ökcün Akçamuş, M. Ç., Akoğlu, G., Kılıç Tülü, B., ve Demir, E. (2021). İlkokul çocuklarına yönelik geliştirilmiş Okuma Yazma Değerlendirme Bataryasının (OYAB) geçerlik ve güvenirlik çalışması. Ana Dili Eğitimi Dergisi, 9(3), 740-770.

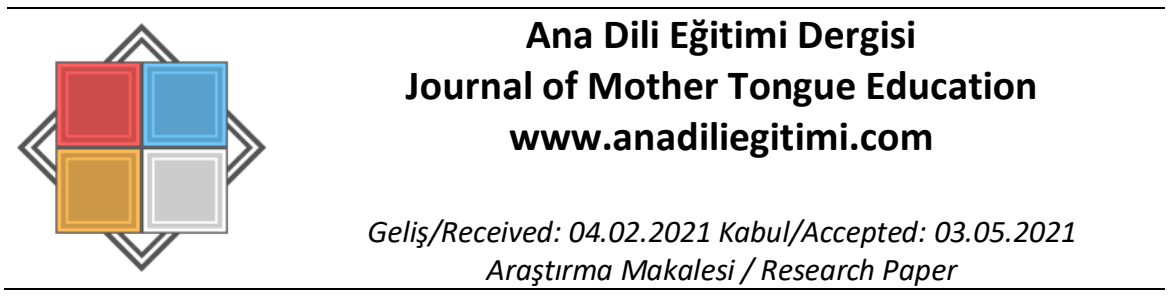

\title{
Illkokul Çocuklarına Yönelik Geliştirilmiş Okuma Yazma Değerlendirme Bataryasının (OYAB) Geçerlik ve Güvenirlik Çalışması*
}

\author{
Cevriye ERGÜL $L^{* *}$ \\ Meral Çilem ÖKCÜN AKÇAMUŞ ${ }^{* * *}$ \\ Gözde AKOĞLU*** \\ BurCU KILIÇ TÜLÜ̈**** \\ Ergül DEMiR ${ }^{* * * * * *}$
}

\begin{abstract}
Öz
Bu araştırmada ilkokula devam eden çocukların, okuma, okuduğunu anlama ve yazma becerilerini ölçmek ve bu alanlarda güçlük yaşayıp yaşamadıklarını belirlemek amacıyla geliştirilmiş olan Okuma Yazma Değerlendirme Bataryasının (OYAB) geçerlik ve güvenirliğinin belirlenmesine yönelik analizlerinin yapılması ve kesme aralıkları ile değerlendirme ölçütlerinin belirlenmesi amaçlanmıştır. Araştırmanın katılımcıları ilkokul 1, 2, 3 ve 4. sınıflara devam eden 1177 çocuktan oluşmaktadır. Katılımcıların sosyoekonomik düzeyleri SED İndeksi Ebeveyn Bilgi Formuyla, okuma yazma becerileri ise OYAB ile değerlendirilmiştir. Analizlerde öncelikle OYAB'ın geçerlik ve güvenirliği incelenmiş, ardından performansı değerlendirmeye yönelik kesme aralıkları belirlenmiştir. Analizler sonucunda OYAB'ın kapsam geçerliğine sahip olduğu, üç faktörlü (okuma, okuduğunu anlama, yazma) bir yapısının olduğu ve bu yapının model uyum indekslerinin her bir sınıf düzeyi için yüksek düzeyde olduğu ve tüm sınıf düzeylerinde alt üst grupları ayırıcılığının yüksek olduğu bulunmuştur. Bataryanın güvenirlik analizlerinde iç tutarlılık katsayısının iyi düzeyde olduğu, test tekrar-test korelasyonları ile A ve B formlarının eş değerlik anlamında korelasyon katsayılarının da yüksek olduğu belirlenmiştir. Ek olarak, bataryanın tüm sınıf düzeylerinde performansa ilişkin "çok düşük, düşük, orta, yüksek, çok yüksek" şeklinde beş düzeyli bir değerlendirme yapılabilmesi için kesme noktaları ve aralıkları belirlenmiştir.
\end{abstract}

Anahtar Kelimeler: Okuma Yazma Değerlendirme Bataryası, OYAB, geçerlik, güvenirlik, kesme aralıkları, değerlendirme ölçütleri

\section{A Study on Validity and Reliability of the Literacy Assessment Battery (LAB) Developed for Primary School Children}

\section{Abstract}

In this study, the aim was to analyze the validity and reliability of the Literacy Assessment Battery (LAB), developed to assess the reading, reading comprehension, and writing skills of children

\footnotetext{
* Bu çalışma TÜBITAK tarafından desteklenen 215 K027 nolu proje kapsamında yürütülmüştür.

${ }^{* *}$ Prof. Dr., Ankara Üniversitesi, Eğitim Bilimleri Fakültesi, Özel Eğitim Bölümü, Ankara, E-posta: cergul@ankara.edu.tr, ORCID: orcid.org/0000-0001-6793-6469

*** Doç. Dr., Ankara Üniversitesi, Eğitim Bilimleri Fakültesi, Özel Eğitim Bölümü, Ankara, E-posta:

okcun@ankara.edu.tr, ORCID: orcid.org/0000-0003-3297-9711

**** Prof. Dr., İzmir Katip Çelebi Üniversitesi, Sağlık Bilimleri Fakültesi, Çocuk Gelişimi Bölümü, İzmir, E-posta: gozde.akoglu@ikcu.edu.tr, ORCID: orcid.org/0000-0002-3685-4310

***** Öğr. Gör. Dr., Ankara Üniversitesi, Eğitim Bilimleri Fakültesi, Özel Eğitim Bölümü, Ankara, E-posta: tulu@ankara.edu.tr, ORCID: orcid.org/0000-0002-9623-8392

${ }^{* * * * * *}$ Doç. Dr., Ankara Üniversitesi, Eğitim Bilimleri Fakültesi, Eğitimde Ölçme ve Değerlendirme Anabilim Dalı, Ankara, E-posta: erguldemir@ankara.edu.tr, ORCID: orcid.org/0000-0002-3708-8013
} 
attending primary school and to determine whether they have difficulties in these areas. The study also aimed to establish cut-off intervals and evaluation criteria for LAB's scores. Participants consist of 1177 children attending the 1st--4th grades of primary school. While socioeconomic status of the participants was determined with the SES Index Parent Information Form, literacy skills were assessed using LAB. In the analyzes, first the validity and reliability of LAB was examined and then the cut-off intervals to evaluate the performance were determined. As a result of the analysis, it was found that LAB had content validity, had a three-factor structure (reading, reading comprehension, and writing) with high model fit indexes for each grade level, and significantly discriminated lower and upper groups at all grade levels. In the reliability analysis of the battery, it was found that the internal consistency coefficient was at a good level, the test-retest correlations, and the correlation coefficients of the equivalence of the $A$ and $B$ forms were also high. In addition, cut-off intervals were determined at all grades in order to make a five-level evaluation of the performance as "very low, low, medium, high, and very high".

Keywords: Literacy Assessment Battery, LAB, validity, reliability, cut-off points, evaluation criteria

\section{Giriş}

Okuma yazma becerileri bireyin akademik başarısı ve bunun doğrudan ve/veya dolaylı bir sonucu olarak toplumsal yaşama etkin katılımında rol oynayan unsurların başında gelmektedir. Bu nedenle, çocuklara okulda öğretilmesi hedeflenen en temel beceri okuma yazma olmaktadır. Çocukların okuma yazma becerilerindeki gelişimi aşamalı bir şekilde gerçekleşmekte, ilkokulun ilk yıllarından başlayarak tüm akademik yaşantı boyunca da devam etmektedir. Yapılan çalışmalarda da, okuma yazma becerilerine ilişkin başarının ilerleyen dönemlerdeki akademik başarıyı yordayan en güçlü değişkenlerden biri olduğu gösterilmiştir (Ou ve Reynolds, 2008; Scales, Benson, Roehlkepartain, Sesma ve van Dulmen, 2006; Willoughby, Wylie ve Little, 2019). Bununla birlikte, okuma-yazma becerilerinin ediniminde ve gelişiminde sıklıkla bireysel farklılıklar da gözlenmekte, aynı sınıf düzeyinde olan ve okuma yazmaya ilişkin aynı formel öğretim sürecinden geçen çocukların okuma yazma başarıları önemli ölçüde farklılaşabilmektedir.

Ulusal ve uluslararası ölçekte yapılan birçok çalışmada farklı sınıf düzeylerinde yer alan pek çok çocuğun okuma yazma becerilerinin edinimi ve gelişiminde akranlarının gerisinde performans sergiledikleri gösterilmiş (örn., Ergül, 2012; Seçkin-Yılmaz ve Baydık, 2017; Snowling, Duff, Nash ve Hulme, 2016; Snowling, Lervag, Nash ve Hulme, 2019), okuma yazmanın bir ya da daha fazla bileşeninde güçlük yaşayan çocukların, bu güçlüklere bağlı olarak daha sonraki yıllarda diğer akademik becerilerde de farklı düzeylerde güçlük yaşadıkları belirtilmiştir. Bu konuda ABD'de gerçekleştirilen bir çalışma, dördüncü sınıf düzeyindeki çocukların \%32'sinin sınıf düzeyinin gerisinde bir okuma performansı gösterdiğini ortaya koymuştur (National Assessment of Educational Progress, 2013). Bu oran sınıfta her üç çocuktan birinin istenen düzeyde okuma başarısı gösterememesi ve akranlarına göre daha yavaş ve hatalı okuması şeklinde yansımaktadır. Diğer taraftan, okuma yazma becerilerinde yaşanan başarısızıkların okul yaşamı boyunca da tutarlı bir şekilde devam ettiğini ve genel bir akademik başarısızlığa dönüştüğünü gösteren çok sayıda araştırma bulunmaktadır (Caglar-Ryeng, Eklund ve Nergard-Nissen, 2019; Cunningham ve Stanovich, 1997; Peng vd., 2019). Araştırmalar, akademik açıdan risk altında olan bireylerin sıklıkla eğitim yaşantısını erken dönemde sonlandırma ve yükseköğretime devam etmeme eğilimi gösterdiklerini, buna bağlı olarak da gelecekte daha düşük statülü işlerde çalıştıklarını ve ekonomik güçlükler yaşadıklarını göstermektedir (Maclean, Taylor ve O’Donnell, 2016; Valdez, Lambert ve lalongo, 2011). Bu çerçevede çocukların okuma yazma becerilerinde yaşadıkları güçlüklerin ayrıntıı olarak ele alınması önemlidir.

\section{Okumada Yaşanan Güçlükler}

Okuma sürecini fiziksel, bilişsel, duygusal, çevresel, dilsel ve eğitsel açıdan pek çok değişken etkilemekte ve bu değişkenlerle ilgili sorunlar başarılı bir okumanın gerçekleşmesine engel olabilmektedir (Akyol ve Sever, 2018). Başarılı bir okuma performansı doğru, akıcı ve anlayarak okuma becerilerini içermektedir. Bir başka deyişle çocuk sınıf düzeyinde bir metni akıcı ve doğru okuduğunda ve okunan metni anlayabildiğinde başarılı bir okumadan söz etmek mümkündür. Genel olarak bu 
beceriler başarılı ve zayıf okuyucuları ayırt edici en güçlü özellikler arasında yer almaktadır (Hudson, Lane ve Pullen, 2005).

Akıcı okuma alanyazında sıklıkla doğru okumayı içerecek şekilde tanımlanmakta ve okuduğunu anlamaya temel oluşturan becerilerden biri olarak kabul edilmektedir. Bu bağlamda akıcı okuma; doğru, uygun hızda, vurgu ve tonlamalara dikkat ederek, metni anlamaya izin verecek şekilde okuma olarak ifade edilmektedir. Bir metni akıcı bir şekilde okuyabilen bir kişi sözcükleri hızlı ve çok çaba harcamadan tanıyabilmekte, metin hakkında yorum yapabilmekte ve okunan metnin içeriğini hatırlayabilmektedir (Lambert, 2007). Yapılan birçok araştırma akıcı, hızlı ve hatasız bir şekilde okuyan kişilerin okuduklarını daha iyi anladıklarını ortaya koymuştur (Kuhn, 2004; Nandhini ve Balasundaram, 2011; National Assessment of Educational Progress, 2013). Ayrıca, akıcı okuma problemlerinin çoğunlukla diğer okuma problemlerine eşlik ettiği ve çoğu durumda öğrenme güçlüğü tanısı açısından önemli bir yordayıcı olduğu da kabul edilmektedir (Hudson, Lane ve Pullen, 2005).

Akıcı okumanın temel olarak doğrululuk, hız ve prozodik okuma olmak üzere üç bileşeni bulunmaktadır. Bunlardan doğruluk bileşeni sözcüklerin doğru bir şekilde tanınmasını içermektedir. Okumanın akıcı bir şekilde gerçekleşebilmesi için öncelikle sözcüklerin doğru okunması gerekmektedir. Sözcük tanıma olarak da ifade edilen bu sürecin başlangıcında çocuklar okuma için daha çok zaman ve çaba sarf etmekte, buna karşın, okumaya ilişkin deneyimleri arttıkça ortografik bilgiyi daha kolay işlemleyerek sözcük tanımayı daha hızlı gerçekleştirmektedirler (Perfetti, 1985; Stanovich, 1991). Akıcı okumanın bileşenlerinden ikincisi olan hız ise sözcüklerin otomatik ve hızlı bir şekilde tanınmasını içermektedir. Herhangi bir beceri hızlı bir şekilde, çok fazla çaba harcamadan, doğrudan bilinçli bir farkındalık olmaksızın, kendiliğinden gerçekleşiyorsa, o becerinin otomatik olarak gerçekleştiği kabul edilebilir (Kuhn, Schwanenflugel ve Meisinger, 2010; Logan, 1997). Buna göre akıcı bir okuma gerçekleştiren okuyucu, sözcüğü tanımak için gözle görülebilir bir mekanizmaya başvurmadan sözcükleri anında geri çağırabilmekte, bu yolla sözcükleri tanıyabilen okuyucular okuma sırasında herhangi bir duraklama yaşamadan okumayı sürdürebilmekte ve bilişsel kaynaklarını okudukları metnin anlamına odaklayabilmektedirler. Okumayı öğrenme sürecinde, çocuklar başlangıçta sözcükleri yavaş okumakta ve bu sırada dikkatlerini metinde yer alan bilgiler ve bunlar arasındaki ilişkiler yerine harfler ve sözcüklere odaklamaktadırlar. Zamanın çoğu sözcükleri çözümlemeye ayrıldığında ise akıcılık sınırlanmakta ve metnin anlaşıması kesintiye uğramaktadır. Bu noktada çocukların okuma deneyimlerinin arttıııması ve bu yolla okuma hızlarının geliştirilmesi önem kazanmaktadır (Kuhn ve diğerleri, 2006).

Akıcı okumanın önemli ve tamamlayıcı diğer bileşeni ise prozodidir. Prozodi; ritimdeki, tondaki, konuşma hızındaki, vurgudaki değişkenlikleri ifade etmektedir (İmer, Kocaman ve Özsoy, 2011). Hızlı ancak vurgu ve tonlamalardan, uygun yerlerde duraklamalardan yoksun bir okuma, okuyucunun ve dinleyicinin metni anlamasını güçleştirmektedir.

Okumanın başarılı bir şekilde gerçekleşebilmesi için okumanın tüm bileşenlerinin bir arada ve yeterli düzeyde sergilenmesi büyük önem taşımaktadır (Chard, Vaughn ve Tyler, 2002; Uzunkol, 2013). $\mathrm{Ne}$ var ki, okuma güçlüğü yaşayan çocuklarda bu bileşenlerin her birinde ayrı ayrı veya bir arada problemler yaşanması söz konusu olabilmektedir. Bu problemler ise yanlış, yavaş ve prozodik olmayan bir okuma olarak kendini göstermektedir. Özellikle yavaş okuma, okumada güçlüğü olan çocuklarda uzun yıllar boyunca devamlılık gösterebilmekte ve okuma performanslarının en belirgin özelliği olarak gözlenebilmektedir. Bu durumlardan herhangi birinin varlığı ise bireysel olarak başarısızlık duygusu yaşanmasına, okumaya yönelik isteğin azalmasına ve okuduğunu anlamaya ilişkin önemli güçlüklerin yaşanmasına yol açmaktadır (Rasinski, 2006).

\section{Okuduğunu Anlamada Yaşanan Güçlükler}

Okuduğunu anlama, metinde sunulan bilgiler ile okuyucunun metnin konusuyla ilgili daha önce var olan bilgilerinin birlikte işlemlenerek yapılandırılmasını içeren aktif bir süreçtir (Scanlon, Anderson ve Sweeney, 2010). Okumanın nihai hedefi olarak tanımlanan okuduğunu anlama becerisi akademik yaşamın ve öğrenmenin de temelini oluşturmaktadır. Okuduğunu anlama olmadan çocukların akademik alanda öğrenmeyi gerçekleştirmeleri çok mümkün değildir. Bu bağlamda, okuduğunu anlama becerisi, eğitim-öğretim sürecinin farklı basamaklarında giderek artan bir önem taşımakta, 
eğitim programının tüm alanlarında çocukların öğrenmeyi gerçekleştirebilmeleri için anahtar rol oynamaktadır.

Okuduğunu anlama becerileri dile dayalı becerilerin işlevsel bir şekilde kullanılmasını gerektirmektedir (Hoover ve Gough, 1990; Hougen, 2014; Perfetti, 2010). Nitekim araştırmacılar, dili anlama becerisinin yokluğunda okuduğunu anlama becerisinden de söz edilemeyeceğini belirtmektedirler. Özellikle ilk okumayı öğrenme sürecinin ardından çocuklar sözcükleri çözümleme konusunda yetkin hale geldikçe, dil becerileri okuduğunu anlama açısından sözcük okuma becerisinden daha önemli hale gelmektedir (Oakhill, Cain ve Elbro, 2019). Bir başka deyişle, iyi bir okuduğunu anlama becerisi için çözümleme becerileri tek başına yeterli değildir, sözcük bilgisi ile yazılı dili ve konuşma dilini yorumlama becerilerine de gereksinim duyulmaktadır (Hoover ve Gough, 1990). Alanyazında pek çok araştırma, okuduğunu anlama güçlükleri yaşayan çok sayıda çocuğun yaşlarıyla uyumlu sözcük okuma becerileri sergilediklerini ve sözcük çözümleme konusundaki güçlü yanlarının genellikle okuduğunu anlamada yaşadıkları güçlükleri maskelediğini göstermektedir (Hoover ve Gough, 1990; Hougen, 2014; Perfetti, 2010; Tannenbaum, Torgesen ve Wagner, 2009). Bu durum, özellikle sözcük çözümleme becerisinin öğrenilmesine odaklanılan formel eğitimin ilk yıllarında söz konusu olmaktadır. Formel eğitim yaşantısının ilerleyen yıllarında öğretim amacı, "okumayı öğrenme"den "öğrenmek için okuma"ya doğru yöneldiğinde okuduğunu anlama güçlüğü yaşayan çocuklar sözcükleri ve dili anlamlandırmada yaşadıkları güçlüklere bağlı olarak giderek daha dezavantajlı hale gelmekte ve güçlükleri ileri düzey öğrenme yaşantılarını engelleyebilmektedir. Yapılan araştırmalar dile bağlı okuduğunu anlama güçlüklerinin özellikle okuma becerilerinin görece yerleşik hale geldiği 8 yaş civarında daha belirgin bir hale geldiğine ve sonraki yıllarda da süreklilik gösterdiğine işaret etmektedir. Ayrıca, sözcük okuma doğruluğu ile okunan bir metne ilişkin soruları yanıtlama performansı arasındaki farkın dile dayalı okuduğunu anlama güçlüklerine ilişkin önemli bir işaret olduğu da alanyazında belirtilmektedir (Clarke, Truelove, Hulme ve Snowling, 2014).

Okuduğunu anlamada yaşanan güçlükler anlamanın farklı düzeylerinde gözlenebilmektedir. Genel olarak bilgiye dayalı, çıkarımsal ve eleştirel anlama olmak üzere üç okuduğunu anlama düzeyinden ve/veya türden söz etmek mümkündür. Bilgiye dayalı anlama; doğrudan metnin içinde yer alan bilginin anlaşılmasını ifade ederken; çıkarımsal anlama, metinde doğrudan belirtilen bilgileri okuyucunun hâlihazırda sahip olduğu bilgilerle birleştirerek çıkarımlar yapmasını içermektedir. Başarılı okuyucular, yazıda bırakılan boşlukları dolduran çıkarımlar yapmak için mevcut bilgilerini kullanırken, yetersiz okuyucular genellikle bunu başaramamaktadırlar (Yuill, Oakhill ve Oakhill, 1991). Eleştirel anlama ise metindeki bilgilerin ne anlama geldiğinin okuyucu tarafından yazarın niyetine, uzmanlığına ve/veya bakış açısına göre değerlendirilmesini içermektedir. Araştırmalar, çözümlemede güçlük yaşamayıp, okuduğunu anlamada güçlük yaşayan çocukların birincil olarak çıkarımsal anlamada güçlük yaşadıklarına dikkat çekmektedir (Perfetti, Landi ve Oakhill, 2005). Yaşanan güçlüklerin nedenleri ise daha çok çocukların uygun çıkarımları yapmak için gerekli bilgiye sahip olmamaları, ne zaman çıkarım yapmaları gerektiğini ayırt edememeleri ve/veya önceki bilgileri ile metinde yer alan bilgiyi birleştirmeye ilişkin işlemleme sınırlılıklarının olması ile ilişkilendirilmektedir (Scanlon vd., 2010; Yuill vd., 1991).

\section{Yazmada Yaşanan Güçlükler}

Yazma becerisi; algısal becerilerin yanı sıra, bilişsel, motor ve dilbilimsel becerileri içeren karmaşık bir süreci ifade etmektedir (Boscolo, 2008). Bu beceri, tek tek seslerin görsel temsillerinin farkında olma becerisinden, uzun ve anlambilimsel olarak karmaşık metinleri yazmaya kadar uzanan çok sayıda beceriyi içermektedir. Illkokuldan yükseköğrenime uzanan süreçte formel eğitimin tüm aşamalarında ve giderek artan düzeyde yazma becerilerine gereksinim duyulmakta; bu beceriler, öğrencilerin bilgilerini, düşüncelerini ve deneyimlerini öğretmenlerine ve sınıf arkadaşlarına sunmalarının temel yolu olarak kabul edilmektedir (Burns, Kidd ve Genarro, 2010). Yazma becerileri aynı zamanda çocukların belirli bir konu hakkındaki fikirlerini keşfetmelerine ve organize etmelerine yardımcı olan, bir konu hakkında bilgi toplamak, var olan bilgileri hatırlamak ve paylaşmak için kullanılan esnek bir araç olarak da görev yapmaktadır (Graham ve Harris, 2005). 
Illk yazma becerileri kapsamında çocuklar harfleri ve sözcükleri kopyalama ve söylendiğinde doğru yazabilme becerileri ile harf yüksekliğini ayarlama, harfler ve sözcükler arasındaki boşlukları düzenleme ve satır çizgisine yerleştirme gibi el yazısına ilişkin diğer temel becerileri geliştirmektedirler. Motor ve görsel işlemleme becerilerinin daha etkili olduğu bu süreçte yazının okunabilirliği ve biçimsel özellikleri yazma becerilerinin göstergesi olmaktadır. Eş zamanlı olarak öğretimi gerçekleştirilen, ancak çocukların ilk yazma becerilerini geliştirdikten sonra daha da önem kazanan doğru yazma becerileri ise çocukların duydukları sözcüklerdeki sesleri ayırt edebilmelerini, seslerin zihinsel temsillerini ve harf karşııılarını üretebilmelerini gerektiren bir beceridir. Bu süreçte başlangıçta çocuklar yoğun olarak sesbilgisel farkındalık becerilerine gereksinim duyarlarken, ilerleyen zamanlarda bu gereksinimleri azalır ve sözcükleri yazarken otomatiklik kazanırlar. Çocukların bilişsel ve dil becerileri ile de yakından ilişkili olan doğru yazma becerileri, yazma becerilerinin edinimi sürecinde ve ilerleyen yıllarda en sık problem yaşanan alanlardan biri olmaktadır. Daha sonraki aşamada geliştirilmesi hedeflenen yazılı ifade becerileri ise, yazmanın ve genel olarak dil becerilerinin en üst düzeydeki ve en karmaşık becerisi olup, yazma becerilerinin nihai hedefini oluşturmaktadır (Graham, 2006).

Algısal, bilişsel, motor ve dil becerilerini içeren karmaşık doğası nedeniyle çok sayıda çocuk yazma becerilerinin edinimi aşamasında veya yazılı ifade becerilerinin gelişiminde önemli güçlükler yaşayabilmektedir. Bu güçlükler, ses-harf eşleştirmede, sözcükleri otomatik ve akıcı bir şekilde yazmada, yazım kurallarına uygun yazmada, yazının içeriğini planlama ve düzenlemede veya sadece okunaklı yazmada olabilmektedir (Afonso, Connelly ve Barnett, 2019). Güçlükler doğru yazma, yazım kuralları, noktalama işaretleri ve el yazısı gibi biçimsel özelliklere dair düşük profilli ve fikir üretme, içeriği sıralama ve gözden geçirme gibi içerik özelliklerine dair daha yüksek profilli güçlükler olarak da ayrılabilmektedir (Saddler, 2006). Alanyazında, yazmanın mekanik boyutunda ve doğru yazmada güçlük yaşayan çocukların özellikle bakarak yazma ve dikte görevlerinde çok sayıda yazım hatası yaptıkları ve çoğunlukla yavaş yazdıkları, yazılı ifade görevlerinde ise yazının içeriğine gereken önemi veremedikleri belirtilmekte, bu durumun onların hem daha az sayıda ve daha düşük nitelikte metin üretmelerine hem de yazılarında daha sık yazım hataları yapmalarına neden olduğu öne sürülmektedir (Akyol ve Sever, 2018; Graham, 2010). Yazılı ifadede güçlük yaşayanların ise çoğunlukla daha kısa yazmaya eğilimli oldukları, yazmaya başlamadan önce düşünme ve planlama yapmak için yeterli zaman ayırmadıkları, yazı için yeterli ve uygun fikirler geliştiremedikleri, fikirlerini organize edemedikleri ve genellikle yazılarını inceleme ve düzenleme konusunda isteksiz davrandıkları belirtilmektedir (Westwood, 2008).

\section{Okuma Yazma Becerilerinin Değerlendirilmesi}

Okuma ve yazma becerilerinin değerlendirilmesi temelde, okuma ve /veya yazma güçlükleri açısından olası risklerin, beceri düzeyinin, bu düzeyin yaş ve sınıf düzeyine uygunluğunun, bu alanlarda herhangi bir güçlük yaşanıp yaşanmadığının ve varsa güçlüklerin içeriğinin ve düzeyinin belirlenmesini amaçlamaktadır. Bu bağlamda, kullanılan değerlendirme yaklaşım ve yöntemlerinin okuma ve yazmaya ilişkin çok sayıda beceriyi kapsamlı bir şekilde ele alması ve edinilen bilgilerin sentezlenmesine olanak tanıması gerektiği belirtilmektedir (Richek, Caldwell, Jennings ve Lerner, 2002). Bununla birlikte, okuma ve yazmaya ilişkin değerlendirmelerin, öğrencilerin başarabildikleri ve henüz başaramadıkları becerilere ve okuma ve yazma düzeyine ilişkin bilgi vermesi gerektiği de vurgulanmaktadır (Lipson ve Wixson, 2009). Alanyazında okuma ve yazma becerilerinin sesbilgisel, ortografik (yazım), anlam, içerik özelliklerinin yanı sıra; akıcılık, doğruluk ve anlama boyutlarına odaklanan çeşitli görev ve işlemleri içeren çok sayıda değerlendirme aracı yer almaktadır (Goldsworthy, 2003; Lipson ve Wixson, 2009).

\section{Türkiye'de Okuma Yazma Becerilerinin Değerlendirilmesi}

Türkçe alanyazın incelendiğinde, yakın tarihte okuma becerileri ve alt boyutlarını değerlendirmeyi amaçlayan geçerli ve güvenilir değerlendirme araçlarındaki artış dikkat çekmektedir. Bunlar arasında yer alan Yanlış Analizi Envanteri okuma hataları ve okuduğunu anlama düzeyini belirlemek amacıyla Akyol (2005) tarafından Türkçeye uyarlanmıştır. Alanyazında yer alan bir diğer araç ise 6-11 yaş arası çocukların okuma güçlüklerini belirlemek ve tanılamak amacıyla geliştirilen Kelime Okuma Bilgisi Testidir. Babür, Haznedar, Erçetin, Özerman ve Çekerek (2011) tarafından geliştirilen 
testte anlamlı ve anlamsız kelime listeleri kullanılarak, özellikle okumanın geliştiği ilk yıllarda, öğrencinin kelime okuma yeterliliğinin değerlendirilmesi amaçlanmaktadır. Illköğretim 1 ile 5. sınıfta öğrenim gören öğrencilerin okuma ve okuduğunu anlama becerilerinin değerlendirilmesi amacıyla Erden ve Çelik (2019) tarafından geliştirilen Sesli Okuma Becerisi ve Okuduğunu Anlama Becerisi Testi (SOBAT) de okuma hızı, okuma akıcılığı, doğru okuma becerisi ve okuduğunu anlama becerisinin değerlendirilmesini amaçlayan standart testlerdendir. SOBAT-II ise 7-11 yaşları arasında olan çocukların okuma hızı, akıcı okuma, doğru okuma becerisi ve okuduğunu anlama becerisini değerlendirmek amacıyla Melekoğlu, Erden ve Çakıroğlu (2019) tarafından geliştirilmiş geçerli ve güvenilir araçlardandır.

Görüldüğü üzere, geliştirilen araçlar sıklıkla okuma becerileri ve alt boyutlarının değerlendirilmesine odaklanmaktadır. Bununla birlikte, diğer akademik alanlarda öğrenmeye temel oluşturması ve akademik başarının en önemli yordayıcılarından biri olması nedeniyle okuma, okuduğunu anlama ve yazma becerilerin kapsamlı bir şekilde değerlendirilmesinin ve varsa yaşanan güçlüğün düzeyinin ve nedenlerinin belirlenmesi büyük önem taşımaktadır. Bu noktada, okuma ve yazmada yaşanan problemin doğasını ortaya koyabilmek için çok boyutlu değerlendirmenin büyük önem taşıdığını vurgulamakta yarar vardır. Ayrıca, yapılacak değerlendirmelerin etkili, duyarlı ve doğru bir ölçüm ortaya koyabilmesi, kolay yorumlanabilmesi, kısa zamanda uygulanabilmesi ve eğitsel müdahale programlarına ışık tutabilmesi de önemlidir (Breznitz, 2005; Katzir vd., 2006; Lambert, 2007; Meisinger, Bloom ve Hynd, 2010). Bu noktadan hareketle geliştirilen Okuma Yazma Değerlendirme Bataryası (OYAB) ile okuma, okuduğunu anlama ve yazma becerilerini ölçmek ve bu yolla çocukların performanslarını inceleyerek, bu alanların herhangi birinde güçlük yaşanıp yaşanmadığını belirlemek amaçlanmıştır. Bu çalışmada birinci sınıftan dördüncü sınıfa kadar olan çocukların okuma, okuduğunu anlama ve yazma becerilerinin değerlendirilmesi amacıyla geliştirilen OYAB'ın geçerlik ve güvenirlik düzeyinin belirlenmesine ve sınıf düzeyinde kesme aralıklarının oluşturulmasına yönelik aşağıdaki sorulara yanıt aranmıştır. OYAB'ın;

1. Kapsam geçerliği ne düzeydedir?

2. Yapı geçerliği ne düzeydedir

3. Alt-üst grup ortalamalarına dayalı olarak ayırıcılık anlamında geçerliği ne düzeydedir?

4. Boylamsal yordayıcılı̆̆ı ne düzeydedir?

5. Ölçüt geçerliği ne düzeydedir?

6. Test-tekrar-test yöntemine dayalı devamlılık/kararlıık anlamında güvenirliği ne düzeydedir?

7. İç tutarlılık anlamında güvenirliği ne düzeydedir?

8. A ve $B$ formlarının eşdeğerlik anlamında güvenirliği ne düzeydedir?

9. Sınıf düzeyinde performansa ilişkin kesme aralıkları ve bu aralıklara yönelik değerlendirme ölçütleri nedir?

\section{Örneklem}

\section{Yöntem}

İlişkisel tarama modellerinden korelasyonel türde desenlenen bu araştırmanın katılımcıları, Ankara ilinin merkez ilçelerinde Milli Eğitim Bakanlığına bağlı ilkokullarda (devlet ve özel) birinci, ikinci, üçüncü ve dördüncü sınıfa devam eden toplam 1177 çocuktan oluşmaktadır. Bu araştırma, deneme ve esas uygulamalar olmak üzere iki aşamada gerçekleştirilmiştir. Buna bağıı olarak da katılımcıların 252'si deneme, $925^{\prime} \mathrm{i}$ ise esas uygulamada yer almıştır.

Araştırmanın deneme uygulaması aşamasında örnekleminin belirlenmesinde tabakalı örnekleme, küme örnekleme ve basit seçkisiz örnekleme yöntemleri birlikte kullanılmışır. Bu kapsamda Ankara'nın merkez ilçelerindeki okullar üç sosyo ekonomik düzeye (SED) göre sınıflandırılmış ve her SED düzeyinden (alt, orta, üst) dörder olmak üzere toplam 9 okul seçkisiz olarak belirlenmiştir. Her okuldan birinci ve ikinci sınıflardan ikişer olmak üzere toplam 4 şube ve her şubeden 7 çocuk şeçkisiz atama yoluyla belirlenmiştir. Çalışma grubunu oluşturacak çocukların tipik gelişim göstermesine, herhangi bir yetersizlik tanısı almamış olmasına, anadilinin Türkçe olmasına, devamsızlık probleminin olmamasına ve yaşının sınıf düzeyine uygun olmasına dikkat edilmiştir. Cinsiyet değişkeni 
dikkate alınarak her okuldan eşit sayıda kız ve erkek çocuk seçilmesine çalışılmıştır. Belirlenen çocukların katılım kriterlerini karşılamadığı durumda aynı sınıftan başka bir çocuk, yine seçkisiz atama yoluyla belirlenerek, çalışmaya dâhil edilmiştir. Deneme uygulaması, 123 kız ve 129 erkek olmak üzere toplam 252 çocukla gerçekleştirilmiştir.

Esas uygulama aşamasındaki örnekleminin belirlenmesinde de deneme uygulamasında olduğu gibi, tabakalı örnekleme, küme örnekleme ve basit seçkisiz örnekleme yöntemleri kullanılmıştır. Her SED düzeyinden (alt, orta, üst) 18 olmak üzere toplam 54 okul seçkisiz olarak belirlenmiştir. Boylamsal verinin toplandığı ilkokul 1 ve 2 . sınıflar için veri toplama aşamasının başlangıcında her okulun birinci sınıflarından iki şube ve her şubeden ortalama dört çocuk seçkisiz atama yoluyla belirlenerek çalışmaya dâhil edilmiştir. 3 ve 4. sınıflar için ise bu 54 okulun $45^{\prime}$ inin (alt orta ve üst SED'den 15'er okul) 3 ve 4. sınıflarından üçer şube her bir şubeden ortalama ikişer çocuk seçkisiz atama yoluyla belirlenerek çalışmaya dahil edilmiştir. Esas uygulamada birinci sınıftan ikinci sınıfın sonuna kadar boylamsal olarak takip edilen 422 çocuk, üçüncü sınıfa devam eden 256 ve dördüncü sınıfa devam eden 247 çocuk yer almıştır. Katılımcı çocukların SED düzeyleri SED İndeksi Ebeveyn Bilgi Formu (Ergül ve Demir, 2017) kullanılarak belirlenmiştir. Esas uygulamanın katılımcılarının 476'sı kız, 449'u erkek çocuklardan oluşmaktadır ve bu çocukların \%30'u alt SED, \%38'i üst SED \%32'si üst SED grubunda bulunan ailelerden gelmektedir.

\section{Veri Toplama Araçları \\ SED indeksi Ebeveyn Bilgi Formu}

SED İndeksi Ebeveyn Bilgi Formu, ailelerin sosyoekonomik düzeylerinin belirlenmesi amacıyla kullanılmaktadır. Ergül ve Demir (2017) tarafından geliştirilen form, anne-babanın öğrenim durumu, meslek statüleri, evdeki sahiplikleri, kitap sahipliği ve kültürel etkinliklere katılımı başıkları altında 23 SED değişkeni içermekte ve alt, orta-alt, orta, orta-üst ve üst olmak üzere beş SED düzeyi tanımlamaktadır. Formun geçerlik güvenirlik çalışmasında, ana sınıfından 4. sınıfa kadar olan toplam 2411 çocuğun ebeveynlerinden veri toplanmış, yapılan analizler sonucunda formun SED indeksine yönelik varyansın \%57'sini açıklayan 5 faktörlü yapısı tanımlanmış ve doğrulanmıştır.

\section{Okuma Yazma Değerlendirme Bataryası (OYAB)}

OYAB birinci sınıftan dördüncü sınıfa kadar olan çocukların okuma, anlama ve yazma becerilerini değerlendirmeye yönelik olarak araştırmacılar tarafından geliştirilmiş bir test bataryasıdır. OYAB'da okumaya ilişkin dört, yazmaya ilişkin üç ve anlamaya ilişkin üç test yer almaktadır. Değerlendirmeler bireysel olarak gerçekleştirilmektedir. Testlerin çoğunluğu süre temelli uygulanmakta ve belirli sürelerde (örn., 1 dakika, 90 saniye) doğru okunan/yazılan sözcüklerin ya da yanıtlanan maddelerin sayısı belirlenmektedir. Her bir testin birbirine paralel olarak oluşturulmuş $A$ ve B formları bulunmaktadır. OYAB kapsamında oluşturulmuş okuma, okuduğunu anlama ve yazma testleri ve içerikleri aşağıda ayrıntılı olarak açıklanmaktadır.

\section{Okuma Testleri}

Anlamlı Sözcük Okuma Testi: Okuma doğruluğu ve akııılığını belirlemek amacıyla geliştirilmiş olan test, hece sayısına göre sıralanmış 100 sözcükten oluşan bir listeyi içermektedir. Bu liste, çocukların ders kitaplarında yer alan sözcüklerle oluşturulmuş bir havuzdan hece sayısına göre seçkisiz olarak seçilmiş sözcüklerden oluşturulmuştur. Listede tek heceli 5 , iki heceli 15 , üç heceli 30 , dört heceli 30, beş heceli 15 ve altı heceli 5 sözcük yer almaktadır. Testin A ve B olmak üzere iki formu bulunmaktadır. Sınıf düzeyine göre font büyüklüğü farklılaşan testin birinci ve ikinci sınıflar ile yapılan değerlendirmelerinde sözcüklerin Talim Terbiye Kurulu Başkanlı̆̆ı (TTKB) Dik Temel Abece Fontu ve 18 punto ile yazılan formu kullanıııken, üçüncü ve dördüncü sınıflar ile yapılan değerlendirmelerinde aynı fontun 14 punto ile yazılan formu kullanılmaktadır. Sözcükler kalın bir kâğıdın ön ve arka tarafına iki sütun şeklinde yerleştirilmiştir. Çocuğun görevi anlaması için uygulama öncesinde altı sözcükten oluşan kısa bir liste ile örnek bir uygulama yapılmakta, ardından asıl uygulamaya geçilmektedir. Süre temelli olarak uygulanan testte çocuğun bir dakikada okuduğu doğru sözcük sayısı performans puanını oluşturmaktadır. 
Anlamsız Sözcük Okuma Testi: Sesbilgisel çözümlemedeki akıcılığı belirlemek üzere kullanılan test, çocukların sözcük dağarcıklarında olmayan, bu nedenle bütün olarak okuyamadıkları ve sesbilgisel çözümleme becerilerinden yararlanmalarını gerektiren 60 anlamsız sözcükten oluşmaktadır. Sözcükler çocukların ders kitaplarında yer alan sözcüklerle oluşturulmuş bir havuzdan, hece sayısına göre seçkisiz olarak belirlenmiş sözcüklerin Türkçe'nin hece yapısına uygun olarak anlamsız hale dönüştürülmesiyle oluşturulmuştur. Sözcüklerin hece sayısına (1-6 hece) göre sıralandığı listede tek heceli 5, iki heceli 10, üç heceli 15, dört heceli 15, beş heceli 10 ve altı heceli 5 sözcük yer almaktadır. Testin A ve B olmak üzere birbirine paralel iki formu bulunmaktadır. Sınıf düzeyine göre font büyüklüğü farklılaşan testin birinci ve ikinci sınıflar ile yapılan değerlendirmelerinde sözcüklerin TTKB Dik Temel Abece Fontu ve 18 punto ile yazılan formu kullanılırken, üçüncü ve dördüncü sınıflar ile yapılan değerlendirmelerinde aynı fontun 14 punto ile yazılan formu kullanılmaktadır. Sözcükler kalın bir kâğıdın ön ve arka tarafına iki sütun şeklinde yerleştirilmiştir. Çocuğun görevi anlaması için uygulama öncesinde altı sözcükten oluşan kısa bir liste ile örnek bir uygulama yapılmakta, ardından asıl uygulamaya geçilmektedir. Süre temelli olarak uygulanan testte çocuğun bir dakikada okuduğu doğru sözcük sayısı performans puanını oluşturmaktadır.

Fonetik Analiz Testi: Sözcüklerdeki sesbirimleri ayırt etme ve harf-ses eşleme becerilerini değerlendiren bir testtir. Çocukların kendilerine söylenen sözcüklerin ilk sesini ayırt etmelerini ve bu sese karşılık gelen harfi kendilerine gösterilen bir kart üzerindeki üç harf arasından belirlemelerini gerektiren bir görev ile değerlendirilmektedir. Her bir sözcük için çocuğa gösterilen üç harf, sözcüğün içerisindeki diğer harfler arasından seçilmiştir. Sözcüğün iki harften oluşması durumunda da üçüncü harfin ilk sese benzer başka bir sesin harfi olmasına dikkat edilmiştir. Görevin sesbirim ayırt etmeyi gerektirmesi nedeniyle sadece tek ve iki heceli sözcükler kullanılmıştır. Toplam 53 sözcükten oluşan testin $A$ ve $B$ olmak üzere birbirine paralel iki formu bulunmaktadır. Çocuğun görevi anlaması için uygulama öncesinde üç sözcük ile örnek bir uygulama yapılmakta, ardından asıl uygulamaya geçilmektedir. Test süre temelli uygulanmakta ve çocukların bir dakikada doğru olarak gösterdikleri harflerin sayısı performans puanını oluşturmaktadır.

Metin Okuma Testi: Metin okuma akıcılı̆ıını belirlemek üzere geliştirilen bu testte çocukların sınıf düzeyindeki öyküleyici ve bilgilendirici metinlerde bir dakikada okudukları doğru sözcük sayısı belirlenmektedir. Birbirine paralel A ve B formları bulunan testte birinci ve ikinci sınıf düzeyinde iki öyküleyici ve iki bilgilendirici olmak üzere toplam dört metin, üçüncü ve dördüncü sınıf düzeyinde de iki öyküleyici ve iki bilgilendirici olmak üzere yine toplam dört metin kullanılmaktadır. Birinci ve ikinci sınıf düzeyinde kullanılan öyküleyici metinler 36-37 cümle ve 145-148 sözcükten oluşurken aynı sınıf düzeyindeki bilgilendirici metinler 25-29 cümle ve 115-116 sözcükten oluşmaktadır. Üçüncü ve dördüncü sınıf düzeyinde kullanılan öyküleyici metinler ise 33-35 cümle ve 160-163 sözcükten oluşurken, aynı sınıf düzeyindeki bilgilendirici metinler 29-36 cümle ve 164-167 sözcükten oluşmaktadır. Metinler Ateşman'ın (1997) okunabilirlik düzeyi hesaplamaları ile incelendiğinde 1-2. sınıf öyküleyici metinlerinin okunabilirlik düzeylerinin çok kolay düzeyde (94.34 ve 94.40), diğer tüm metinlerin okunabilirlik düzeylerinin ise kolay düzeyde (73.77 ile 85.18 arası) olduğu bulunmuştur. Sınıf düzeyine göre font büyüklüğü farklılaşan testin birinci ve ikinci sınıflar ile yapılan değerlendirmelerinde metinlerin TTKB Dik Temel Abece Fontu ve 18 punto ile yazılan formu kullanılırken, üçüncü ve dördüncü sınıflar ile yapılan değerlendirmelerinde aynı fontun 14 punto ile yazılan formu kullanılmaktadır. Süre temelli olarak uygulanan testte çocuğun öyküleyici ve bilgilendirici metinde bir dakikada okuduğu doğru sözcük sayılarının ortalaması performans puanını oluşturmaktadır.

Okuduğunu Anlama Testleri

Metin Anlama Testi: Çocukların okuduğunu anlama becerilerinin metinlerle değerlendirilmesini amaçlayan testte Metin Okuma Testinde kullanılan metinlerden yararlanılmaktadır. Çocukların Metin Okuma Testinde okudukları öyküleyici ve bilgilendirici metni ikinci kez sessiz olarak okumaları istenmekte ve ardından her bir metne ilişkin altı bilgi ve üç çıkarım sorusunu yanıtlamaları beklenmektedir. Sorular sözel olarak sorulmakta ve çocuklar da sözel olarak yanıtlamaktadır. Belirli bir süresi olmayan testte çocuğun öyküleyici ve bilgilendirici metinde doğru olarak yanıtladığı soru sayılarının ortalaması performans puanı olarak belirlenmektedir. 
Cümle Doğruluğu Testi: Okuduğunu anlama becerilerini değerlendirmek amacıyla geliştirilmiş testte çocukların okudukları cümleleri anlambilimsel (semantik) açıdan değerlendirmeleri ve cümlenin doğru olup olmadığını belirlemeleri beklenmektedir. Testte, anlambilimsel olarak doğru olan ve olmayan toplam 45 cümle yer almaktadır. Çocuklardan cümleleri okuduktan sonra yanıtlarını cümlelerin yanında yer alan iki yüz ifadesinden (mutlu ve üzgün) uygun olanı işaretleyerek belirtmeleri beklenmektedir. Testin benzer karmaşıklığa ve anlamsal özelliklere sahip iki formu (A ve B) bulunmaktadır. Sınıf düzeyine göre font büyüklüğü farklılaşan testin birinci ve ikinci sınıflar ile yapılan değerlendirmelerinde testin TTKB Dik Temel Abece Fontu ve 18 punto ile yazılan formu kullanılırken, üçüncü ve dördüncü sınıflar ile yapılan değerlendirmelerinde aynı fontun 14 punto ile yazılan formu kullanılmaktadır. Çocuğun görevi anlaması için uygulama öncesinde iki madde ile örnek bir uygulama yapılmakta, ardından asıl uygulamaya geçilmektedir. Süre temelli olarak uygulanan testte çocuğun 90 saniyede doğru olarak tanımladığı madde sayısı performans puanı olarak belirlenmektedir.

Boşluk Doldurma Testi: Çocukların okuduğunu anlama becerilerinin değerlendirilmesi amacıyla geliştirilen testte çocuklardan iki cümleden oluşan bir maddenin ikinci cümlesinde boş bırakılan bir sözcüğü, cümlelerdeki anlambilimsel ipuçlarından yola çıkarak belirlemeleri beklenmektedir. Maddelerin ilk cümlesinde bir durum tanımlanmakta, ikinci cümlede ise bu duruma uygun bir olay sunulmaktadır. İkinci cümlede bir sözcüğün yeri boş bırakılmakta ve çocuklardan maddenin hemen altında kendisine sunulan üç alternatif sözcükten cümlenin anlamına uygun olanı belirlemesi ve o seçeneği işaretlemesi istenmektedir. Test, iki ile on bir sözcükten oluşan cümleleri içeren ve karmaşıklığa bağlı olarak kolaydan zora doğru sıralanan 32 maddeden oluşmaktadır. Testin benzer karmaşıklığa ve anlamsal özelliklere sahip iki formu (A ve B) bulunmaktadır. Sınıf düzeyine göre font büyüklüğü farklılaşan testin birinci ve ikinci sınıflar ile yapılan değerlendirmelerinde TTKB Dik Temel Abece Fontu ve 18 punto ile yazılan formu kullanılırken, üçüncü ve dördüncü sınıflar ile yapılan değerlendirmelerinde aynı fontun 14 punto ile yazılan formu kullanılmaktadır. Çocuğun görevi anlaması için uygulama öncesinde iki madde ile örnek bir uygulama yapılmakta, ardından asıl uygulamaya geçilmektedir. Süre temelli olarak uygulanan testte çocuğun iki dakikada doğru olarak tamamladığı madde sayısı performans puanı olarak belirlenmektedir.

\section{Yazma Testleri}

Dikte Testi: Çocukların dikte görevlerindeki yazma doğruluğunu ve akıcılığını değerlendirmek amacıyla geliştirilmiş bir testtir. Çocuklardan kendilerine sözel olarak sunulan (dikte edilen) sözcükleri mümkün olduğunca doğru ve hızı bir şekilde yazmaları beklenmektedir. Test, çocukların ders kitaplarında yer alan sözcükleri içeren havuzdan hece sayısına göre seçkisiz olarak belirlenmiş sözcüklerle oluşturulmuştur. Toplam 40 sözcüğün bulunduğu listede tek heceli 12 , iki heceli 12, üç heceli 10 ve dört heceli 6 sözcük yer almaktadır. Uygulama sırasında her bir sözcük sırayla, açık ve anlaşılır bir şekilde iki kez ardı ardına söylenmekte ve çocuktan söylenen sözcüğü yazması istenmektedir. Testin A ve B olmak üzere birbirine paralel iki formu bulunmaktadır. Çocuğun görevi anlaması için uygulama öncesinde üç sözcük ile örnek bir uygulama yapılmakta, ardından asıl uygulamaya geçilmektedir. Süre temelli olarak uygulanan testte çocuğun 90 saniyede doğru olarak yazdığı sözcük sayısı performans puanı olarak belirlenmektedir.

Bakarak Yazma Testi: Çocukların bakarak yazma görevlerindeki yazma doğruluğunu ve akıcılığını değerlendirmek amacıyla geliştirilmiş bir testtir. Çocuklardan kendilerine yazılı olarak verilen kısa bir metni aynı sayfadaki boş satırlara mümkün olduğunca doğru ve hızlı bir şekilde kopyalamaları beklenmektedir. Testin A ve B olmak üzere birbirine paralel iki formu bulunmaktadır. Her bir formda 11 cümle 51 sözcükten oluşan birer kısa metin yer almaktadır. Süre temelli olarak uygulanan testte çocuğun 90 saniyede doğru olarak yazdığı sözcük sayısı performans puanı olarak belirlenmektedir. Yalnızca birinci sınıfın güz döneminde yapılan değerlendirmede sözcük sayısı yerine çocuğun 90 saniyede doğru olarak yazdığı harf/karakter sayısı performans puanı olarak belirlenmektedir.

Metin Yazma Testi: Çocukların yazılı ifade becerilerini değerlendirmeye yönelik bir testtir. Çocuklardan kendilerine gösterilen ve bir olay anlatan resimlere bakarak bir öykü yazmaları beklenmektedir. Testin A ve B olmak üzere iki formu bulunmaktadır. Her bir formda birbiriyle ilişkili olan ve bir öykü oluşturmaya uygun şekilde serim, düğüm, çözüm bölümlerini içeren üç resim 
bulunmaktadır. Resimler gösterildikten sonra çocuklara öyküye ilişkin planlama yapmaları için 30 saniye verilmekte ve ardından öyküyü yazmaya başlamaları istenmektedir. Çocuk metin yazmayı tamamlayana kadar resimler çocuğun önünde durmakta, çocuğun görevi tamamlaması için belirli bir süre bulunmamakta, kendisi bitirdiğini belirttiği zaman uygulama sonlandırımaktadır. Çocukların yazdıkları öyküler yazılan doğru sözcük sayısı ve metnin biçimsel ve içerik kalitesi açısından ayrı ayrı değerlendirilmektedir. Testte metnin biçimsel ve içerik kalitesi rubrikler aracılığıyla incelenmektedir. Biçimsel Kalite Rubriği harflerin şekilleri, büyüklükleri, satır takibi, yazım doğruluğu ve okunabilirliği gibi yedi alanda $3^{\prime} l u ̈$ değerlendirme yaparken, İçerik Kalitesi Rubriği öykü bölümleri, öğeleri, zihinsel ve duygusal ifade oluşturma, sözcük seçimi ve dil bilgisi gibi sekiz alanda 4'lü değerlendirme yapmaktadır. Çocukların doğru olarak yazdıkları sözcük sayısı ile her iki rubrikten elde ettikleri puanlar testteki performans puanları olarak belirlenmektedir. Metin Yazma Testi çocukların okuma yazma becerilerindeki gelişim düzeyleri nedeniyle birinci sınıfın güz döneminde uygulanmamakta, bahar döneminden itibaren uygulanmaya başlanmaktadır.

\section{Verilerin Toplanması}

Verilerin toplanması aşamasında öncelikle il Milli Eğitim Müdürlüğünden araştırma ile ilgili gerekli izinler alınmış ve veri toplanacak olan okulların yöneticileri ile görüşülerek araştırmanın amacı, veri toplama süreci açıklanmıştır. Araştırmaya katılıma istekli olan okullar belirlenerek uygulayıcı eğitimlerine başlanmıştır.

OYAB uygulamaları özel eğitim alanında yüksek lisans ve doktora düzeyinde eğitim alan 12 uygulayıcı tarafından gerçekleştirmiştir. Bu kapsamda öncelikle uygulayıcılara testin uygulanmasına ve puanlanmasına yönelik bir dizi eğitim verilmiş ve örnek uygulamalarının video kayıtları gösterilmiştir. Ardından uygulayıcılar birbirleri ile uygulamalar yapmışlar ve her bir uygulamaya ilişkin testi geliştiren araştırmacılardan geri bildirim almışlardır. Devamında ise uygulayıcıların kendi uygulama yeterliklerini geliştirmek üzere beş yetişkin ve beş çocuk ile değerlendirme yapmaları istenmiş, son iki uygulamaları araştırmacılar tarafından izlenerek geribildirim verilmiştir. Tüm uygulamacılar testleri istenilen şekilde uygulayabilene kadar bu eğitim süreci sürdürülmüştür. Uygulayıcıların eğitimin ardından verilerin toplanması aşamasına geçilmiştir.

OYAB'ın geçerlik ve güvenirlik çalışmaları deneme ve esas uygulama olmak üzere iki aşamada gerçekleştirilmiştir. Deneme uygulamaları A ve B formunun her ikisinin de uygulandığı 252 çocukla gerçekleştirilmiştir. Esas uygulama kapsamında ise 401 çocuk, birinci sınıftan ikinci sınıfın sonuna kadar boylamsal olarak takip edilerek hem güz hem de bahar döneminde OYAB ile değerlendirilmiştir. Esas uygulamada, ayrıca, üçüncü sınıfa devam eden 256 ve dördüncü sınıfa devam eden 247 çocuğa da OYAB uygulanmıştır. Üçüncü ve dördüncü sınıfta yürütülen değerlendirmeler güz döneminde Kasım ve Aralık aylarında tamamlanmıştır. Testler bireysel olarak sınıf dışında okulun sağladığı sessiz ve dikkat dağıtıcı uyaranların kısıtlandığı bir ortamda uygulanmış, test süreci her bir çocuk için yaklaşık olarak 2535 dakika içinde tamamlanmıştır. Uygulamaların \%15'ine ilişkin ses kayıtları alınmıştır. Alınan bu kayıtlar aracılığıyla testin uygulanması sırasında yapılması gerekenler (çocukla olumlu bir sözel ilişkinin kurulması, testin içeriğinin ve amacının anlatılması, yönergelerin doğru olarak verilmesi, cevaplara yönelik uygun ve yansız ifadeler kullanılması, sürenin etkili bir şekilde kullanılması ve cevapların doğru şekilde puanlandırılması) geliştirilen bir form üzerinde değerlendirilmiştir.

\section{Verilerin Analizi}

OYAB'ın geçerlik ve güvenirlik analizleri yapılmadan önce verilerin betimsel istatistikleri ve normallik varsayımının karşılama durumu incelenmiştir. Bu kapsamda her bir test için ortalama puan, mod, medyan, standart sapma, basıklık ve çarpıklık katsayıları incelenmiş, genel olarak testlerin standart sapma ortalama oranlarının $1 / 4$ ve $1 / 5$ 'e yakın olduğu, basıklık ve çarpıklık $-1+1$ aralığında olduğu ya da bu aralığa yakın olduğu, mod, medyan ve ortalama puanların birbirine yakın olduğu görülmüştür. Tüm bu sonuçlar, normal dağılıma güçlü bir kanıt oluşturmuştur. Betimsel istatistiklerin incelenmesinin ardından OYAB'ın geçerlik ve güvenirlik analizleri gerçekleştirilmiştir. Bu kapsamda OYAB'ın geçerliğini belirlemek amacıyla kapsam geçerliği, yapı geçerliği, ayırıcılık, boylamsal yordayıcılık ve ölçüt geçerliği analizleri yapılmış; güvenirliği belirlemek amacıyla ise iç tutarlılık, test 
tekrar test ve A-B formlarının eşdeğerlik güvenirlik analizleri yapılmıştır. Kapsam geçerliği için uzman görüşleri alınmış, yapı geçerliği için açımlayıcı faktör analizi (AFA) ve doğrulayıcı faktör analizi (DFA) yapılmış, ayırıcılık geçerliği için bağımsız örneklemler t testi, boylamsal yordama geçerliği için basit regresyon analizi ve ölçüt geçerliği için ise Pearson Momentler Çarpımı Korelasyon Katsayısı kullanılmıştır. Güvenirlik analizleri kapsamında da OYAB'ın iç tutarlılığı Cronbach alfa katsayısı ile incelenirken test tekrar test güvenirliği ve $A$ ve $B$ formlarının eş değerlik anlamında güvenirliği ise Pearson momentler Çarpımı Korelasyon Katsayısı ile incelenmiştir. Son olarak, tüm test puanlarının ve bileşik puanların normal dağılım göstermesi nedeniyle kesme puanlarının belirlenmesinde ortalama ve standart sapmaya dayalı bağıl değerlendirme ölçütleri kullanılmış ve her bir sınıf düzeyi ve dönemi için performansı değerlendirmeye yönelik kesme aralıkları ve bu aralıklara yönelik değerlendirme ölçütleri belirlenmiştir. Tüm analizler SPSS ve Lisrel paket programları kullanılarak gerçekleştirilmiştir.

\section{Araştırma ve Yayın Etiği}

Bu çalışmada "Yükseköğretim Kurumları Bilimsel Araştırma ve Yayın Etiği Yönergesi" kapsamında uyulması belirtilen tüm kurallara uyulmuştur. Yönergenin ikinci bölümü olan "Bilimsel Araştırma ve Yayın Etiğine Aykırı Eylemler" başlığı altında belirtilen eylemlerden hiçbiri gerçekleştirilmemiştir.

\section{Etik Kurul izni}

Kurul adı= Ankara Üniversitesi Etik Kurulu

Karar tarihi $=13 / 3 / 2014$

Belge sayı numarası $=1110$

\section{Bulgular}

Bu çalışmada, OYAB'ın geçerliğini belirlemek amacıyla kapsam, yapı, ayırıcılık, boylamsal yordama ve ölçüt geçerliğine yönelik analizler gerçekleştirilirken, güvenirliğini belirlemek amacıyla da iç tutarlık, test tekrar test güvenirlik ve A-B formlarının eşdeğerlik anlamında güvenirliği analizleri gerçekleştirilmiştir. Ayrıca tüm sınıf düzeylerinde performansın değerlendirilebilmesine yönelik kesme aralıkları ve değerlendirme ölçütleri belirlenmiştir.

\section{OYAB'ın Kapsam Geçerliğine Yönelik Bulgular}

OYAB'ın kapsam geçerliğini incelemek üzere testlerin oluşturulması aşamasında Sınıf Öğretmenliği, Özel Eğitim, Türkçe Öğretmenliği, Dil Bilim ve Ölçme-Değerlendirme alanlarından sekiz uzmanın görüşüne başvurulmuştur. Uzmanlardan testlerin ve testlerde yer alan maddelerin sınıf düzeylerine uygunluğunu, maddelerin sıralanışını ve oluşturulmasında temel alınan ölçütlerin (hece yapıları, hece/sözcük/cümle uzunlukları, anlamsız sözcüklerin Türkçede ya da başka bir dilde anlamı olup olmadığı vb.) gerçekleştirilip gerçekleştirilmediğini ve $A / B$ formlarının paralelliğini değerlendirmeleri istenmiştir. Bu değerlendirmelerde uzmanlardan tüm testler ve maddeler için üçlü dereceleme (1=Uygun; 2=Düzeltilmeli; 3=Uygun Değil) ile puanlama yapmaları ve düzeltilmesini önerdikleri ya da uygun görmedikleri maddelere ilişkin gerekçelerini ve önerilerini yazmaları istenmiştir. Ek olarak, uzmanlardan testin tamamlanması için öngörülen sürelere ilişkin görüşlerini içeren kısa açıklamalar yazmaları istenmiştir. Uzmanların yaptıkları değerlendirmelerin analizi ile OYAB kapsamında yer alan tüm testlerde 1.00-1.25 arasında değişen ortalamalar elde edilmiş ve testlerin kapsam geçerliğine sahip olduğu belirlenmiştir. Ayrıca, uzmanların "Düzeltilmeli" değerlendirmesini yaptıkları maddelerde önerileri doğrultusunda gerekli düzenlemeler yapılmış ve son hali verilerek testler uygulamaya hazır hale getirilmiştir.

\section{OYAB'ın Yapı Geçerliğine Yönelik Bulgular}

OYAB'ın yapı geçerliğine yönelik analizleri deneme uygulaması örneklemi ve esas uygulama örneklemi üzerinden ayrı ayrı yürütülmüştür. Analiz sonuçları aşağıda özetlenmiştir. 


\section{OYAB'ın Deneme Uygulamasında Yapı Geçerliğine Yönelik Elde Edilen Bulgular}

OYAB'ın yapı geçerliği çalışmaları kapsamında ilk olarak deneme uygulaması örneklemi üzerinde analizler yapılmıştır. Alt test toplamlarına yönelik betimsel istatistikler incelenmiştir. Buna göre, okuma, anlama ve yazma alanlarındaki tüm testlerden elde edilen puanların ortalama ve medyan değerleri birbirine yakındır. Çocukların tüm becerilerdeki performanslarının çarpıklık ve basıklık değerleri, genel olarak \pm 1 aralığında ve sıfıra yakındır. Metin içerik kalitesi alt testi için basıklık değerinin 1.5 civarında olduğu, bununla birlikte simetri açısından ciddi bir sorun bulunmadığı da görülmektedir. Buna göre tüm testlerdeki puanların normallik açısından kabul edilebilir olduğu görülmektedir (Tabachnick ve Fidell, 2013).

OYAB'ın yapı geçerliğini test etmek amacıyla; ilgili alanyazın temelinde kuramsal bir model kurulmuş ve model-veri uyumu DFA ile test edilmiştir. ilgili alanyazın bağlamında tanımlanan kuramsal model Şekil 1'de verilmiştir.

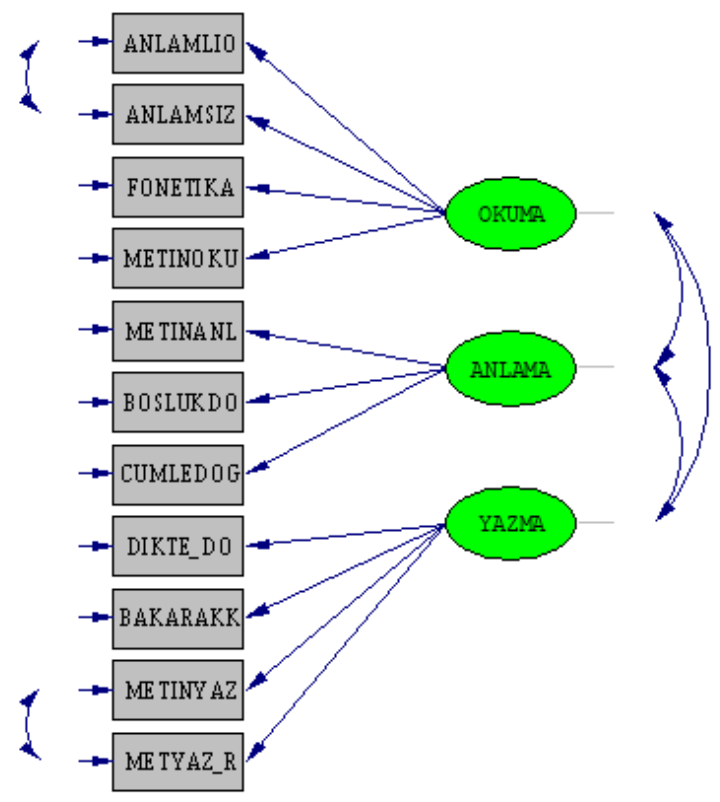

Şekil 1. OYAB'ın Deneme Uygulamalarında Test Edilen Kuramsal Modeli

Şekil 1'de görüldüğü gibi çocukların okuma ve yazma becerileri dörder, anlama becerileri ise üç teste dayalı olarak tanımlanmıştır. Kuramsal model toplamda üç gizil ve 11 gözlenen değişken içermektedir. Her çocuk hem A formlarını hem de B formlarını yanıtladığı için Şekil 1'de verilen kuramsal model A formlarından hem B formlarından elde edilen veriler için ayrı ayrı test edilmiştir. Modele yönelik olarak elde edilen standart yol katsayıları Tablo 1'de verilmiştir.

Tablo 1.

Testlere Yönelik Modelin Standartlaştırılmış Yol Katsayıları

\begin{tabular}{lcccc}
\hline \multirow{2}{*}{ Testler } & \multicolumn{2}{c}{ A formu } & \multicolumn{2}{c}{ B formu } \\
\cline { 2 - 5 } Anlamlı Sözcük Testi & SYK & Hata & SYK & Hata \\
Anlamsız Sözcük Testi & 0.94 & 0.11 & 0.92 & 0.16 \\
Fonetik Analiz Testi & 0.71 & 0.50 & 0.76 & 0.43 \\
Metin Okuma Testi & 0.44 & 0.80 & 0.46 & 0.79 \\
Metin Anlama Testi & 0.96 & 0.08 & 0.97 & 0.06 \\
Cümle Doğruluğu Testi & 0.48 & 0.77 & 0.54 & 0.71 \\
Boşluk Doldurma Testi & 0.93 & 0.13 & 0.91 & 0.18 \\
Dikte Testi & 0.86 & 0.26 & 0.89 & 0.21 \\
Bakarak Yazma Testi & 0.82 & 0.33 & 0.83 & 0.31 \\
Metin Yazma Testi & 0.88 & 0.23 & 0.87 & 0.24 \\
& 0.62 & 0.62 & 0.63 & 0.60
\end{tabular}


ilkokul Çocuklarına Yönelik Geliştirilmiş Okuma Yazma Değerlendirme Bataryasının (OYAB) Geçerlik ve Güvenirlik Çalışması

$\begin{array}{lllll}\text { Metnin İçerik Kalitesi } & 0.46 & 0.79 & 0.52 & 0.73\end{array}$

*Tüm katsayılar .01 düzeyinde manidardır. SYK: Standartlaştırılmış Yol Katsayısı

Tablo 1'de görüldüğü gibi hem A hem B formu verilerine yönelik modellerde, standart hata değerleri .90 'ın altındadır. Tüm yol katsayı değerleri istatistiksel olarak anlamlıdır. Tüm değerler birbirine yakındır ve sıralamaları aynıdır. Bunun yanı sıra $A$ ve $B$ formlarına yönelik model-veri uyumu indeks değerleri incelenmiştir. Buna göre, $\mathrm{A}\left(\mathrm{X}^{2} / \mathrm{sd}=2.48, \mathrm{GFI}=0.93, \mathrm{CFI}=0.99, \mathrm{NFI}=0.98, \mathrm{RMSEA}=\right.$ $0.08, \mathrm{SRMR}=0.04, \mathrm{CN}=166.00)$ ve $\mathrm{B}\left(\chi^{2} / \mathrm{sd}=2.76, \mathrm{GFI}=0.93, \mathrm{CFI}=0.98, \mathrm{NFI}=0.97, \mathrm{RMSEA}=0.08\right.$, $S R M R=0.04, C N=141.95$ ) formları için modelin uyum iyiliği indeksleri yüksek düzeydedir. Test edilen yapısal modelin yüksek model-veri uyumu ile doğrulanması, bileşik toplam puanların kullanılabileceğini göstermektedir. Bu kapsamda okumaya yönelik dört, anlamaya yönelik üç, yazmaya yönelik dört değişken ile bileşik toplam puanı oluşturmak mümkündür. Aynı yapı bir bütün olarak 11 değişken ile bütünleşik okuma-anlama-yazma toplam puanı oluşturulmasının da mümkün olduğunu göstermektedir.

\section{OYAB'ın Esas Uygulamasında Yapı Geçerliğine Yönelik Elde Edilen Bulgular}

OYAB'ın esas uygulamaları kapsamında ilk olarak, birinci sınıftan dördüncü sınıfa kadar olan düzeylerde çocukların okuma, anlama ve yazma testlerinden elde ettikleri puanlar betimsel olarak incelenmiştir. Bu incelemelerde tüm sınıf düzeylerinde ve tüm dönemlerde genel olarak ortalama, mod ve medyan değerlerinin birbirine yakın olduğu; standart sapmaların ortalamanın $1 / 4-1 / 5$ aralığında ya da bu aralığa yakın olduğu belirlenmiştir. Ayrıca basıklık ve çarpıklık katsayıları da genel olarak [-1, +1] aralığındadır ya da bu aralığa yakındır. Tüm değerler, testlere yönelik toplam puanların normal dağıldığının varsayılabileceğini göstermektedir.

Betimsel incelemelerin ardından OYAB'ın yapı geçerliğini test etmek amacıyla; esas uygulamadan elde edilen veriler kullanılarak, öncelikle AFA yapılmış, ardından DFA ile model veri uyumu her bir dönem için test edilmiştir. AFA kapsamında her bir dönem için okuma, anlama ve yazma ile ilişkili değişkenlerin tek boyutlu bir yapı oluşturup oluşturmadığı test edilmiştir. Esas uygulama örneklemi üzerinde yapılan bu analizlerde deneme örnekleminden farklı olarak yazma testlerine metin yazma testinde yazının biçimsel kalitesini belirlemeyi içeren bir değişken daha eklenmiştir. Buna göre, okuma becerileri ile ilişkilendirilmiş dört değişken ile okuma becerisi bileşik toplam puanı, anlama becerileri ile ilişkilendirilmiş üç değişken ile anlama becerileri bileşik toplam puanı ve yazma becerileri ile ilişkilendirilmiş beş değişken ile yazma becerileri bileşik toplam puanı oluşturulmuştur. Ardından tüm bu değişkenlerin bir bütün olarak bileşik okuma, anlama, yazma toplam puanı oluşturduğu belirlenmiştir. Bu kapsamda ifade edilen her bir toplam puan için doğrusal regresyon analizi temelinde regresyon puanları oluşturulmuş ve veri setinde tanımlanarak ileri analizlerde kullanılmaya hazır hale getirilmiştir.

Her bir alt boyutta yürütülen AFA sonuçlarına göre "tek boyutluluğun" sağlandığına yönelik yeterli kanıtın olmasına bağlı olarak, her bir alt boyut toplam puanları, sürekli gözlenen değişkenler olarak belirlenmiş ve analize dahil edilmiştir. Elde edilen verilerin model veri uyumunu test etmek amacıyla DFA yapılmıştır. Buna göre Şekil 2'de OYAB'ın esas uygulamasında test edilen kuramsal modele yer verilmiştir. 


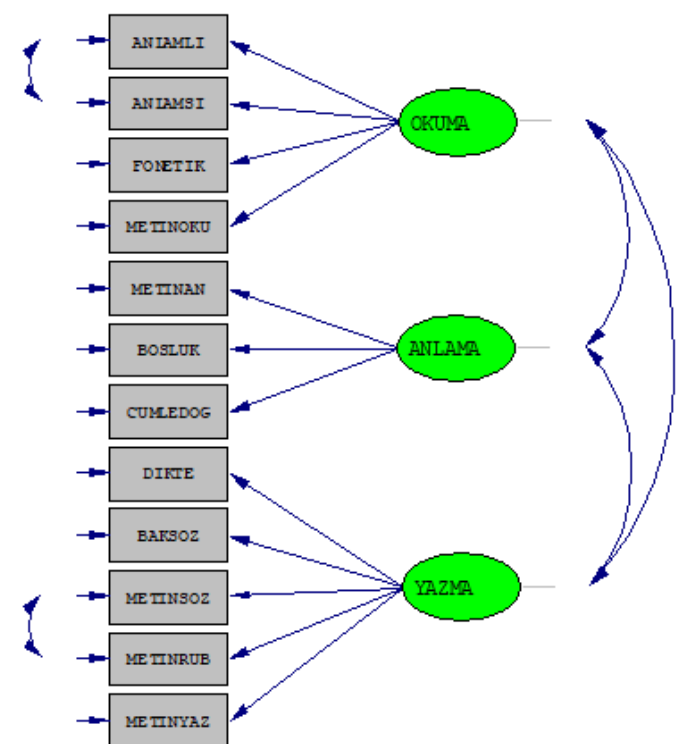

Şekil 2. OYAB'ın Esas Uygulamalarda Test Edilen Kuramsal Modeli

Şekil 2'de gösterilen ve OYAB'ın tüm sınıf düzeyleri için test edilen kuramsal modeli birincil düzey yapısal modeldir. Birinci sınıfın güz dönemi hariç tüm sınıf düzeyleri ve dönemler için çocukların okuma becerileri dört, anlama becerileri üç ve yazma becerileri ise beş değişken temelinde tanımlanmıştır. Buna karşın, birinci sınıf güz döneminde modelde yazma becerilerine ait değişkenlerin sayısında bir farklılaşmakla olmuştur. Metin yazma becerilerinin gelişimi birinci sınıf güz döneminde çok sınırlı düzeyde gerçekleştiğinden, metin yazma testi bu dönemde uygulanmamış ve yazma üç değişkene dayalı olarak modellenmiştir. Sonuç olarak, kuramsal model birinci sınıf güz döneminde toplamda üç gizil, 10 gözlenen değişken içerirken, diğer dönemlerde üç gizil ve 12 gözlenen değişken içermektedir. Tüm sınıf düzeylerinde testler arasında gerekli modifikasyonlar yapılmıştır. Sınıf düzeylerine yönelik model veri uyum iyiliği değerlerine Tablo 2'de yer verilmiştir.

Tablo 2.

Sınıf Düzeyleri ve Dönemlerine Göre Model-Veri Uyumu Indeks Değerleri

\begin{tabular}{lcccccc}
\hline Indeks & $\begin{array}{c}\text { 1. Sinıf } \\
\text { Güz }\end{array}$ & $\begin{array}{c}\text { 1. Sinıf } \\
\text { Bahar }\end{array}$ & $\begin{array}{c}2 . \text { Sinıf } \\
\text { Güz }\end{array}$ & $\begin{array}{c}\text { 2. Sinıf } \\
\text { Bahar }\end{array}$ & 3. Sinıf & 4. Sınıf \\
\hline$\chi^{2} / \mathrm{sd}$ & 2.87 & 2.81 & 3.26 & 3.78 & 1.53 & 2.04 \\
GFI & 0.96 & 0.95 & 0.94 & 0.95 & 0.95 & 0.94 \\
CFI & 0.99 & 0.98 & 0.97 & 0.98 & 0.99 & 0.98 \\
NFI & 0.99 & 0.98 & 0.96 & 0.97 & 0.97 & 0.95 \\
RMSEA & 0.07 & 0.06 & 0.07 & 0.08 & 0.05 & 0.06 \\
RMR & 0.03 & 0.06 & 0.07 & 0.05 & 0.05 & 0.04 \\
\hline
\end{tabular}

Tablo 2'de görüldüğü gibi model veri uyumuna yönelik değeri $x^{2}$ değerleri anlamlıdır ve $x^{2} / s d$ oranları $5^{\prime}$ in altındadır. Bu değerler mükemmel model-veri uyumuna işaret etmektedir. Hata terimlerine yönelik RMSEA ve RMR değerleri her iki dönem için .03 ile .10 arasında olup değerler kabul edilebilir düzeyde model-veri uyumu olduğunu göstermektedir. Diğer uyum iyiliği indeksleri ise $.90^{\prime} ı n$ üzerindedir ve değerler mükemmele yakın model-veri uyumunu yansıtmaktadır. Uyum iyiliğine yönelik tüm bu kestirimler birlikte değerlendirildiğinde, OYAB'ın yüksek düzeyde model-veri uyumunu sağladığı düşünülmektedir. Modellere yönelik standartlaştırılmış yol katsayıları ve hata değerleri tüm sınıf düzeyleri için Tablo 3'te verilmiştir. 
İlkokul Çocuklarına Yönelik Geliştirilmiş Okuma Yazma Değerlendirme Bataryasının (OYAB) Geçerlik ve Güvenirlik Çalışması

Tablo 3.

Testlere Yönelik Modelin Standartlaștırılmış Yol Katsayıları

\begin{tabular}{|c|c|c|c|c|c|c|c|c|c|c|c|c|}
\hline \multirow[b]{2}{*}{ Testler } & \multicolumn{2}{|c|}{$\begin{array}{l}\text { 1. Sınıf } \\
\text { Güz }\end{array}$} & \multicolumn{2}{|c|}{$\begin{array}{l}\text { 1. Sinıf } \\
\text { Bahar }\end{array}$} & \multicolumn{2}{|c|}{$\begin{array}{l}\text { 2. Sinıf } \\
\text { Güz }\end{array}$} & \multicolumn{2}{|c|}{$\begin{array}{l}\text { 2. Sinıf } \\
\text { Bahar }\end{array}$} & \multicolumn{2}{|c|}{ 3. Sinıf } & \multicolumn{2}{|c|}{ 4. Sinıf } \\
\hline & SYK & Hata & SYK & Hata & SYK & Hata & SYK & Hata & SYK & Hata & SYK & Hata \\
\hline Anlamlı Sözcük Testi & 0.96 & 0.08 & 0.92 & 0.16 & 0.93 & 0.13 & 0.93 & 0.13 & 0.88 & 0.22 & 0.87 & 0.24 \\
\hline Anlamsız Sözcük Testi & 0.94 & 0.11 & 0.80 & 0.36 & 0.81 & 0.35 & 0.86 & 0.29 & 0.75 & 0.43 & 0.68 & 0.54 \\
\hline Fonetik Analiz Testi & 0.56 & 0.69 & 0.43 & 0.81 & 0.39 & 0.85 & 0.35 & 0.88 & 0.25 & 0.94 & 0.29 & 0.92 \\
\hline Metin Okuma Testi & 0.93 & 0.16 & 0.97 & 0.06 & 0.96 & 0.08 & 0.87 & 0.05 & 0.95 & 0.10 & 0.94 & 0.12 \\
\hline Metin Anlama Testi & 0.56 & 0.66 & 0.54 & 0.71 & 0.39 & 0.85 & 0.34 & 0.88 & 0.32 & 0.90 & 0.03 & 1.00 \\
\hline Cümle Doğruluğu Testi & 0.95 & 0.10 & 0.86 & 0.25 & 0.83 & 0.31 & 0.82 & 0.33 & 0.85 & 0.28 & 0.89 & 0.20 \\
\hline Boşluk Doldurma Testi & 0.88 & 0.23 & 0.90 & 0.19 & 0.91 & 0.18 & 0.95 & 0.10 & 0.89 & 0.21 & 0.89 & 0.21 \\
\hline Dikte Testi & 0.76 & 0.43 & 0.73 & 0.47 & 0.72 & 0.49 & 0.63 & 0.60 & 0.68 & 0.54 & 0.70 & 0.51 \\
\hline Bakarak Yazma Testi & 0.39 & 0.85 & 0.67 & 0.55 & 0.80 & 0.36 & 0.80 & 0.36 & 0.82 & 0.31 & 0.84 & 0.30 \\
\hline Metin Yazma Testi & - & - & 0.58 & 0.66 & 0.49 & 0.76 & 0.45 & 0.79 & 0.44 & 0.81 & 0.21 & 0.95 \\
\hline Metnin Biçimsel Kalitesi* & 0.20 & 0.86 & 0.61 & 0.83 & 0.50 & 0.75 & 0.40 & 0.84 & 0.17 & 0.97 & 0.15 & 0.96 \\
\hline Metnin İçerik Kalitesi & - & - & 0.41 & 0.63 & 0.49 & 0.76 & 0.49 & 0.76 & 0.30 & 0.91 & 0.19 & 0.98 \\
\hline
\end{tabular}

* Birinci sınıf güz döneminde bu değişken Bakarak Yazma Testinden elde edilen yazı örnekleri üzerinden değerlendirilmiştir.

**Tüm katsayılar .01 düzeyinde manidardır, SYK: Standartlaştırılmış Yol Katsayısı 
Tüm sınıf düzeyleri için alt testler ve OYAB arasında pozitif korelasyonlar bulunmaktadır. Tablo 3'te görüldüŭg̈ gibi, birinci ve ikinci sınıfın tüm dönemleri ile üçüncü sınıfta yol katsayı değerlerinin tümü istatistiksel olarak anlamlıyken, dördüncü sınıfta Metin Anlama Testi dışında yol katsayılarının tümü anlamlıdır. Metin Anlama Testinin, dördüncü sınıf düzeyinde çocukların okuduğunu anlama becerilerinin değerlendirilmesinde önemli bir değişken olması ve diğer model-veri uyum iyiliği indekslerinin iyi olması nedeni ile modelde kalması yönünde karar verilmiştir. Birinci ve ikinci sınıfın tüm dönemlerinde standart hata değerleri .90'ın altındayken üçüncü ve dördüncü sınıfta bazı hata terimlerinin $.90^{\prime} ı$ üzerinde olduğu görülmektedir. Üçüncü ve dördüncü sınıfta yüksek olan bu hata terimlerinin, tüm uyum iyiliği indeksleri birlikte değerlendirildiğinde, kabul edilebilir olduğuna karar verilmiştir. Birinci sınıfın güz döneminde okumanın en iyi yordayıcısı Anlamlı Sözcük Okuma, anlamanın en iyi yordayıcısı Cümle Doğruluğu, yazmanın en iyi yordayıcısı ise Dikte Testidir. Birinci sınıfın bahar ve ikinci sınıfın güz dönemlerinde okumanın en iyi yordayıcısı Metin Okuma, anlamanın en iyi yordayıcısı Boşluk Doldurma Testidir. Yazmanın ise birinci sınıfın bahar döneminde en iyi yordayıcısı Dikte Testi iken, ikinci sınıfın güz döneminde Bakarak Yazma Testidir. İkinci sınıfın bahar döneminde okumanın en iyi yordayıcısı Anlamlı Sözcük Testi, anlamanın en iyi yordayıcısı Boşluk Doldurma, yazmanın en iyi yordayıcısı ise Bakarak Yazma Testidir. Üçüncü ve dördüncü sınıf düzeylerinde okuma, anlama ve yazmayı en iyi yordayan değişkenlere bakıldığında her iki sınıf düzeyinde de okumayı en iyi Metin Okuma Testinin, anlamayı Boşluk Doldurma Testinin ve yazmayı da Bakarak Yazma Testinin yordadığı gözlenmiştir.

\section{OYAB'ın Ayırıcılık Geçerliğine Yönelik Bulgular}

OYAB'ın ayırıcılık geçerliği çalışmaları kapsamında esas uygulama örneklemi üzerinde alt-üst gruplara dayalı analizler yapılmıştır. Bu kapsamda, tüm sınıf düzeyleri ve dönemler için testler ve bileşik puanlara yönelik ortalama puanların farklılaşıp farklılaşmadığı bağımsız örneklemler $t$ testi kullanarak incelenmiştir. Elde edilen bulgular birinci ve ikinci sınıf için Tablo 4'te, üçüncü ve dördüncü sınıf için Tablo 5'te verilmiştir. 
İlkokul Çocuklarına Yönelik Geliştirilmiş Okuma Yazma Değerlendirme Bataryasının (OYAB) Geçerlik ve Güvenirlik Çalışması

Tablo 4

OYAB Bileşik Puanlarının Birinci ve Ikinci Sınıf Düzeylerinde Alt-Üst Gruplara Dayalı Ayırıcılık Düzeyleri

\begin{tabular}{|c|c|c|c|c|c|c|c|c|c|c|c|c|c|}
\hline \multirow{2}{*}{ Testler } & \multirow{2}{*}{ Dönem } & \multicolumn{6}{|c|}{ 1. Sinif } & \multicolumn{6}{|c|}{ 2. Sinif } \\
\hline & & Grup & $\mathrm{N}$ & $\mathrm{X}$ & ss & $\mathrm{t}$ & $\eta 2$ & Grup & $\mathrm{N}$ & $x$ & ss & $\mathrm{t}$ & $\eta 2$ \\
\hline \multirow{4}{*}{ Okuma Bileşik Puanı } & \multirow{2}{*}{ Güz } & Alt & 253 & 37.49 & 13.08 & \multirow{2}{*}{$23.95^{*}$} & \multirow{2}{*}{0.56} & Alt & 208 & 120.80 & 25.57 & \multirow{2}{*}{$28.29 *$} & \multirow{2}{*}{0.65} \\
\hline & & Üst & 191 & 84.83 & 27.62 & & & Üst & 219 & 189.33 & 24.49 & & \\
\hline & \multirow{2}{*}{ Bahar } & Alt & 240 & 96.79 & 19.38 & \multirow{2}{*}{$28.23^{*}$} & \multirow{2}{*}{0.66} & Alt & 203 & 140.31 & 26.91 & \multirow{2}{*}{$28.26^{*}$} & \multirow{2}{*}{0.65} \\
\hline & & Üst & 205 & 157.43 & 25.84 & & & Üst & 221 & 212.97 & 26.02 & & \\
\hline \multirow{4}{*}{ Anlama Bileşik Puanı } & \multirow{2}{*}{ Güz } & Alt & 229 & 4.95 & 3.62 & \multirow{2}{*}{$29.85 *$} & \multirow{2}{*}{0.68} & Alt & 231 & 26.41 & 4.82 & \multirow{2}{*}{$25.43^{*}$} & \multirow{2}{*}{0.60} \\
\hline & & Üst & 198 & 18.12 & 5.42 & & & Üst & 197 & 38.77 & 5.22 & & \\
\hline & \multirow{2}{*}{ Bahar } & Alt & 232 & 19.67 & 4.28 & \multirow{2}{*}{$26.89 *$} & \multirow{2}{*}{0.62} & Alt & 236 & 29.35 & 5.40 & \multirow{2}{*}{$28.04 *$} & \multirow{2}{*}{0.71} \\
\hline & & Üst & 209 & 30.92 & 4.49 & & & Üst & 189 & 43.92 & 5.22 & & \\
\hline \multirow{4}{*}{ Yazma Bileşik Puanı } & \multirow{2}{*}{ Güz } & Alt & 261 & 40.87 & 8.43 & \multirow{2}{*}{$23.10^{*}$} & \multirow{2}{*}{0.53} & Alt & 233 & 58.63 & 11.77 & \multirow{2}{*}{$26.00 *$} & \multirow{2}{*}{0.62} \\
\hline & & Üst & 196 & 63.72 & 12.68 & & & Üst & 190 & 95.07 & 16.96 & & \\
\hline & \multirow{2}{*}{ Bahar } & Alt & 234 & 50.14 & 9.01 & & & Alt & 232 & 66.06 & 11.38 & & \\
\hline & & Üst & 199 & 74.46 & 10.29 & $26.21^{*}$ & 0.61 & Üst & 192 & 101.02 & 15.45 & $26.18^{7}$ & 0.63 \\
\hline & Gïz & Alt & 232 & 84.95 & 22.49 & $2407 *$ & 057 & Alt & 218 & 213.78 & 38.13 & $2831 *$ & 066 \\
\hline OYAB Bileşik Puanı & Guz & Üst & 191 & 160.51 & 40.89 & $24.0 \%$ & 0.57 & Üst & 205 & 316.79 & 36.61 & $28.31^{*}$ & 0.66 \\
\hline & & Alt & 232 & 173.78 & 28.26 & & & Alt & 215 & 245.56 & 39.87 & & \\
\hline & Bahar & Üst & 196 & 258.17 & 32.98 & $28.50^{2}$ & 0.66 & Üst & 207 & 349.96 & 37.53 & $21.67^{*}$ & 0.65 \\
\hline
\end{tabular}


İlkokul Çocuklarına Yönelik Geliştirilmiş Okuma Yazma Değerlendirme Bataryasının (OYAB) Geçerlik ve Güvenirlik Çalışması

Tablo 4'e göre, birinci ve ikinci sınıflar için, tüm bileşik puanlarda alt-üst gruplar arasında .001 düzeyinde anlamlı fark vardır. Etki büyüklüklerinin oldukça yüksek düzeyde olduğu dikkati çekmektedir $(.56-.71)$.

Tablo 5.

OYAB Bileşik Puanlarının Üçüncü ve Dördüncü Sınıf Düzeylerinde Alt-Üst Gruplara Dayalı Ayırıcılık Düzeyleri

\begin{tabular}{|c|c|c|c|c|c|c|c|c|c|c|c|}
\hline \multirow[b]{2}{*}{ Testler } & \multirow[b]{2}{*}{ Grup } & \multicolumn{5}{|c|}{ 3. Sinif } & \multicolumn{5}{|c|}{ 4. Sinif } \\
\hline & & $\mathrm{N}$ & $x$ & ss & $\mathrm{t}$ & $\eta 2$ & $\mathrm{~N}$ & $x$ & ss & $\mathrm{t}$ & $\eta 2$ \\
\hline \multirow{2}{*}{$\begin{array}{l}\text { Okuma } \\
\text { Bileşik } \\
\text { Puanı }\end{array}$} & Alt & 117 & 177.06 & 22.80 & \multirow{2}{*}{$21.39 *$} & \multirow{2}{*}{0.66} & 119 & 206.84 & 23.96 & \multirow{2}{*}{$20.56^{*}$} & \multirow{2}{*}{0.64} \\
\hline & Üst & 124 & 239.52 & 22.51 & & & 124 & 271.53 & 25.04 & & \\
\hline \multirow{2}{*}{$\begin{array}{l}\text { Anlama } \\
\text { Bileşik } \\
\text { Puanı }\end{array}$} & Alt & 129 & 39.87 & 4.61 & \multirow{2}{*}{$21.05 *$} & \multirow{2}{*}{0.65} & 123 & 45.29 & 5.52 & \multirow{2}{*}{$20.55^{*}$} & \multirow{2}{*}{0.64} \\
\hline & Üst & 112 & 53.06 & 5.12 & & & 120 & 61.84 & 6.96 & & \\
\hline \multirow{2}{*}{$\begin{array}{l}\text { Yazma } \\
\text { Bileşik } \\
\text { Puanı }\end{array}$} & Alt & 126 & 79.02 & 10.20 & \multirow{2}{*}{$20.42 *$} & \multirow{2}{*}{0.64} & 135 & 98.94 & 12.82 & \multirow{2}{*}{$20.25 *$} & \multirow{2}{*}{0.63} \\
\hline & Üst & 115 & 111.22 & 14.11 & & & 108 & 139.31 & 18.20 & & \\
\hline \multirow{2}{*}{$\begin{array}{l}\text { OYAB } \\
\text { Bileşik } \\
\text { Puanı }\end{array}$} & Alt & 111 & 299.09 & 33.27 & \multirow{2}{*}{$22.05^{*}$} & \multirow{2}{*}{0.67} & 123 & 361.04 & 40.76 & \multirow{2}{*}{$20.20^{*}$} & \multirow{2}{*}{0.63} \\
\hline & Üst & 130 & 392.70 & 32.47 & & & 120 & 460.58 & 35.85 & & \\
\hline
\end{tabular}

Tablo 5'e göre, üçüncü ve dördüncü sınıflarda da tüm testlerde ve bileşik puanlarda alt-üst gruplar arasında .001 düzeyinde anlamlı farklar bulunmuştur. Etki büyüklükleri ise $.63-.67$ arasında değişen yüksek etki büyüklüğü değerlerine ulaşmıştır. Bu durum OYAB'ın ayırıcılık anlamında geçerlik düzeyinin yüksek olduğu şeklinde değerlendirilmiştir.

\section{OYAB'ın Boylamsal Yordayıcılığına ilişskin Bulgular}

OYAB'ın boylamsal yordayıcılığının belirlenmesine yönelik olarak birinci sınıfın güz ve bahar dönemlerindeki okuma, anlama ve yazma bileşik puanlarının ikinci sınıfın güz ve bahar dönemlerindeki OYAB bileşik puanlarını yordama durumu incelenmiştir. Bunun için ilk olarak, çocukların birinci sınıfın güz döneminde elde ettikleri okuma, anlama ve yazma bileşik puanlarının ikinci sınıfın güz ve bahar dönemindeki OYAB bileşik puanını yordama düzeyi incelenmiştir. Doğrusal regresyon analizi kullanarak yapılan analizlerin sonuçları Tablo 6'da verilmiştir.

Tablo 6.

Birinci Sınıf Güz Dönemindeki Okuma, Anlama ve Yazma Bileşik Puanlarının ikinci Sınıf Güz-Bahar Dönemindeki OYAB Bileşik Puanına Etkisi

\begin{tabular}{lccccccc}
\hline \multirow{2}{*}{ Dönem } & Yordayıcl & $B$ & $\mathrm{SH}$ & $\mathrm{B}$ & $\mathrm{t}$ & $\mathrm{p}$ & $\mathrm{R}^{2}$ \\
\hline \multirow{4}{*}{ Güz } & (Sabit) & 200.97 & 9.65 & & 20.82 & .000 & \\
& Okuma & 0.54 & 0.17 & .27 & 3.05 & .002 & .36 \\
& Anlama & 2.69 & 0.70 & .34 & 3.84 & .000 & \\
& Yazma & 0.03 & 0.22 & .00 & 0.14 & .884 & \\
\multirow{4}{*}{ Bahar } & (Sabit) & 259.05 & 9.70 & & 26.69 & .000 & \\
& Okuma & 0.47 & 0.18 & .25 & 2.65 & .008 & .32 \\
& Anlama & 2.59 & 0.69 & .35 & 3.75 & .000 & \\
& Yazma & -0.65 & 0.23 & -.02 & -0.29 & .775 & \\
\hline
\end{tabular}


Tablo 6'da görüldüğü gibi, kurulan çoklu doğrusal regresyon modeli ikinci sınıf güz dönemi $\left(F=64.94, \mathrm{sd}_{1}=3, \mathrm{sd}_{2}=348, p<.001\right)$ ve bahar $\left(F=54.44, \mathrm{sd}_{1}=3, \mathrm{sd}_{2}=347, p<.001\right)$ dönemi için manidardır. Birinci sınıf güz dönemindeki okuma ve anlama bileşik puanları ikinci sınıf güz dönemindeki OYAB bileşik puanını anlamlı olarak yordamakta ve bu model toplam varyansın yaklaşık \%60'ını açıklamaktadır ( $R=.60, R^{2}=.36$, Düzeltilmiş $R^{2}=.35$ ). Birinci sınıf güz dönemindeki okuma ve anlama bileşik puanları ikinci sınıf bahar dönemindeki OYAB bileşik puanını da anlamlı olarak yordamakta ve bu model varyansın \%57'sini açıklamaktadır $\left(R=.57, R^{2}=.32\right.$, Düzeltilmiş $\left.R^{2}=.31\right)$. íki dönemde de modele en çok katkı sağlayan yordayıcı anlama bileşik puanı olmuştur. Buna karşın, her iki dönemde de yazma puanı ikinci sınıftaki OYAB bileşik puanlarını anlamlı olarak yordamamıştır.

OYAB'ın yordama geçerliği kapsamında ikinci olarak, çocukların birinci sınıfın bahar dönemindeki okuma, anlama ve yazma bileşik puanlarının ikinci sınıfın güz ve bahar dönemindeki OYAB bileşik puanını yordama düzeyi incelenmiştir. Doğrusal regresyon analizi kullanarak yapılan analizlerin sonuçları Tablo 7'de verilmiştir.

Tablo 7.

Birinci Sınıf Bahar Dönemi Okuma, Anlama ve Yazma Puanlarının Ikinci Sınıf Güz-Bahar Dönemi OYAB Bileşik Puanına Etkisi

\begin{tabular}{cccccccc}
\hline \multirow{2}{*}{ Dönem } & Yordayıcl & $B$ & SH & $B$ & $T$ & $p$ & $R^{2}$ \\
\hline \multirow{4}{*}{ Güz } & (Sabit) & 72.76 & 9.31 & & 7.82 & .000 & \\
& Okuma & 0.78 & 0.10 & .47 & 8.17 & .000 & .59 \\
& Anlama & 1.36 & 0.52 & .16 & 2.62 & .009 & \\
& Yazma & 1.01 & 0.16 & .25 & 6.24 & .000 & \\
\hline \multirow{4}{*}{ Bahar } & (Sabit) & 145.54 & 10.07 & & 14.45 & .000 & \\
& Okuma & 0.66 & 0.11 & .41 & 6.04 & .000 & .48 \\
& Anlama & 1.33 & 0.58 & .16 & 2.29 & .023 & \\
& Yazma & 0.84 & 0.17 & .22 & 4.79 & .000 & \\
\hline
\end{tabular}

Tablo 7'de görüldüğü gibi, kurulan çoklu doğrusal regresyon modeli ikinci sınıf güz dönemi $\left(F=173.83, \mathrm{sd}_{1}=3, \mathrm{sd}_{2}=367, p<.001\right)$ ve bahar dönemi $\left(F=111.70, \mathrm{sd}_{1}=3, \mathrm{sd}_{2}=365, p<.001\right)$ için manidardır. Birinci sınıf bahar dönemindeki okuma, anlama ve yazma bileşik puanları ikinci sınıf güz dönemi OYAB bileşik puanını anlamlı olarak yordamakta ve bu model toplam varyansın yaklaşık $\% 77$ 'sini açıklamaktadır $\left(R=.77, R^{2}=.59\right.$, Düzeltilmiş $\left.R^{2}=.58\right)$. Benzer şekilde birinci sınıf bahar dönemindeki okuma, anlama ve yazma bileşik puanları ikinci sınıf bahar dönemindeki OYAB bileşik puanını anlamlı olarak yordamakta ve bu model varyansın \%69'unu açıklamaktadır $\left(R=.69, R^{2}=.48\right.$, Düzeltilmiş $\left.R^{2}=.47\right)$. Her iki dönemde de modele en çok katkı sağlayan yordayıcılar sırasıyla okuma, yazma ve anlama bileşik puanları olmuştur.

\section{OYAB'ın Ölçüt Geçerliğine ilişkin Bulgular}

OYAB'ın ölçüt geçerliği çalışmaları esas uygulama örneklemi üzerinde gerçekleştirilmiştir. Ölçüt geçerliği çalışmaları kapsamında çocukların okuma, anlama, yazma ve OYAB bileşik puanları ile alanyazında sıklıkla ilişkili olduğu belirtilen harf bilgisi, sesbilgisel farkındalık, çalışma belleği, hızlı isimlendirme, sözel dil ve sözcük bilgisi değişkenleri arasındaki ilişkiler incelenmiştir. Değişkenler arasındaki ilişkiler Pearson Momentler Çarpımı Korelasyon Katsayısı kullanılarak hesaplanmış ve sonuçlar birinci sınıf için Tablo 8'de, ikinci sınıf için ise Tablo 9'da verilmiştir. 
İlkokul Çocuklarına Yönelik Geliştirilmiş Okuma Yazma Değerlendirme Bataryasının (OYAB) Geçerlik ve Güvenirlik Çalışması

Tablo 8.

Birinci Sınıf Ölçüt Geçerliği Düzeyleri

\begin{tabular}{lcccccccc}
\hline & Dönem & Harf Bilgisi $\begin{array}{c}\text { Sesbilgisel } \\
\text { Farkındalık }\end{array}$ & $\begin{array}{c}\text { Hızlı } \\
\text { menlendir } \\
\text { me }\end{array}$ & $\begin{array}{c}\text { Çalışma } \\
\text { Belleği }\end{array}$ & Sözel Dil & $\begin{array}{c}\text { Alııı Dil } \\
\text { Sözcük } \\
\text { Bilgisi }\end{array}$ & $\begin{array}{c}\text { ífade Edici } \\
\text { Dil Sözcük } \\
\text { Bilgisi }\end{array}$ \\
\hline Okuma & Güz & $.342^{* *}$ & $.343^{* *}$ & $-.295^{* *}$ & $.270^{* *}$ & $.261^{* *}$ & $.149^{* *}$ & $.180^{* *}$ \\
\cline { 2 - 8 } Bileşik & Bahar & $.177^{* *}$ & $.332^{* *}$ & $-.439^{* *}$ & $.302^{* *}$ & $.172^{* *}$ & $.163^{* *}$ & $.177^{* *}$ \\
\hline Anlama & Güz & $.422^{* *}$ & $.416^{* *}$ & $-.352^{* *}$ & $.382^{* *}$ & $.312^{* *}$ & $.236^{* *}$ & $.300^{* *}$ \\
\cline { 2 - 8 } Bileşik & Bahar & $.197^{* *}$ & $.368^{* *}$ & $-.391^{* *}$ & $.342^{* *}$ & $.264^{* *}$ & $.249^{* *}$ & $.310^{* *}$ \\
\hline Yazma & Güz & $.197^{* *}$ & $.128^{* *}$ & $-.200^{* *}$ & $.159^{* *}$ & $.168^{* *}$ & $.104^{*}$ & $.103^{*}$ \\
\cline { 2 - 8 } Bileşik & Bahar & $.228^{* *}$ & $.292^{* *}$ & $-.335^{* *}$ & $.261^{* *}$ & $.220^{* *}$ & $.126^{* *}$ & $.112^{* *}$ \\
\hline OYAB & Güz & $.349^{* *}$ & $.342^{* *}$ & $-.300^{* *}$ & $.286^{* *}$ & $.256^{* *}$ & $.137^{* *}$ & $.197^{* *}$ \\
\cline { 2 - 8 } Bileşik & Bahar & $.201^{* *}$ & $.341^{* *}$ & $-.443^{* *}$ & $.313^{* *}$ & $.205^{* *}$ & $.178^{* *}$ & $.195^{* *}$ \\
\hline
\end{tabular}

${ }^{*} p<0.01 ;{ }^{* *} p<0.01$

Tablo 8' de görüldüğü gibi birinci sınıf güz döneminde yani okuma-yazma öğretiminin yoğun bir şekilde sürdürüldüğü bir süreçte değerlendirilen tüm değişkenler birbiriyle anlamlı düzeyde $(p<.01)$ ilişkilidir. Okuma bileşik puanı harf bilgisi ve sesbilgisel farkındalık ile orta düzeyde ilişkili iken diğerleri ile düşük düzeyde ilişkilidir. Anlama bileşik puanı alıcı dil sözcük bilgisi ile düşük düzeyde ilişkili iken diğer tüm değişkenler ile orta düzeyde ilişkilidir. En yüksek ilişkili olduğu değişken ise harf bilgisidir $(r=.42)$. Yazma bileşik puanı ise tüm değişkenlerle düşük düzeyde ilişkili olarak bulunmuştur. Son olarak, OYAB bileşik puanı harf bilgisi, sesbilgisel farkındalık ve hızlı isimlendirme ile orta düzeyde ilişkili iken diğer değişkenlerle düşük düzeyde ilişkilidir. Hızlı isimlendirme ile olan ilişkilerin negatif yönlü olması, hızlı isimlendirme ölçümlerinin doğası gereği daha kısa sürede tamamlanan isimlendirmenin, yani düşük puanların, daha yüksek bir performansa işaret etmesi ile ilintilidir.

Bahar döneminde de tüm değişkenler birbiriyle anlamlı düzeyde $(p<.01)$ ilişkilidir. Okuma bileşik puanı sesbilgisel farkındalık ve çalışma belleği ile orta düzeyde ilişkilidir. Anlama bileşik puanı sesbilgisel farkındalık, çalışma belleği ve ifade edici sözcük bilgisi ile orta düzeyde ilişkilidir. Yazma testleri hızlı isimlendirme dışındaki tüm değişkenlerle pozitif yönlü ve düşük ilişkilidir. Son olarak OYAB bileşik puanı sesbilgisel farkındalık ve çalışma belleği değişkenleri ile orta düzeyde ilişkiliyken diğer tüm değişkenlerle düşük düzeyde ilişkilidir. Hızlı isimlendirme ile tüm değişkenler arasında negatif ve orta düzeyde bir ilişki vardır.

Tablo 9.

ikinci Sınıf Ölçüt Geçerliği Düzeyleri

\begin{tabular}{|c|c|c|c|c|c|c|c|}
\hline & Dönem & $\begin{array}{l}\text { Harf } \\
\text { Bilgisi }\end{array}$ & $\begin{array}{l}\text { Sesbilgisel } \\
\text { Farkındalık }\end{array}$ & $\begin{array}{c}\text { Hızlı } \\
\text { İsimlendirme } \\
\text { Harf }\end{array}$ & $\begin{array}{l}\text { Çalışma } \\
\text { Belleği }\end{array}$ & $\begin{array}{l}\text { Alıcı Dil } \\
\text { Sözcük } \\
\text { Bilgisi }\end{array}$ & $\begin{array}{c}\text { Ifade } \\
\text { Edici Dil } \\
\text { Sözcük } \\
\text { Bilgisi }\end{array}$ \\
\hline \multirow{2}{*}{ Okuma Bileşik } & Güz & .095 & $.398 * *$ & $-.403 * *$ & $.307^{* *}$ & $.180 * *$ & $.194^{* *}$ \\
\hline & Bahar & $.195^{* *}$ & $.377^{* *}$ & $-.338 * *$ & $.266^{* *}$ & $.253^{* *}$ & $.254^{* *}$ \\
\hline \multirow{2}{*}{ Anlama Bileşik } & Güz & .094 & $.431^{* *}$ & $-.367 * *$ & $.411^{* *}$ & $.320 * *$ & $.334 * *$ \\
\hline & Bahar & $.183^{* *}$ & $.373 * *$ & $-.257 * *$ & $.422 * *$ & $.384 * *$ & $.368 * *$ \\
\hline \multirow{2}{*}{ Yazma Bileşik } & Güz & .043 & $.365^{* *}$ & $-.239 * *$ & $.217^{* *}$ & $.134^{* *}$ & $.100 * *$ \\
\hline & Bahar & $.112^{*}$ & $.246^{* *}$ & $-.017 * *$ & $.215^{* *}$ & $.174^{* *}$ & $.138^{* *}$ \\
\hline \multirow{2}{*}{ OYAB Bileşik } & Güz & .083 & $.426 * *$ & $-.394 * *$ & $.320 * *$ & $.202 * *$ & $.197^{* *}$ \\
\hline & Bahar & $.183^{* *}$ & $.360 * *$ & $-.272 * *$ & $.334^{* *}$ & $.270 * *$ & $.245^{* *}$ \\
\hline
\end{tabular}

${ }^{*} p<0.01 ; * * p<0.01$ 
Tablo 9'da görüldüğü gibi güz dönemi için harf bilgisi hariç tüm değişkenler birbirleriyle anlamlı düzeyde $(p<.01)$ ilişkilidir. Okuma bileşik puanı sesbilgisel farkındalık ve çalışma belleği ile orta düzeyde ilişkiliyken hızlı isimlendirme ile negatif yönlü ve orta düzeyde ilişkilidir. Anlama bileşik puanı harf bilgisi hariç diğer tüm değişkenlerle orta düzeyde ilişkilidir. Bu ilişki hızlı isimlendirme ile negatif yönlü iken, diğer değişkenlerle pozitif yönlüdür. Yazma bileşik puanı sesbilgisel farkındalıkla orta düzeyde ilişkilidir. Yazma hızlı isimlendirme ile düşük ve negatif ilişkiliyken, çalışma belleği ve alıcı dil sözcük bilgisiyle düşük ve pozitif yönlü ilişkilidir. Son olarak OYAB bileşik puanları sesbilgisel farkındalık ve çalışma belleği değişkenleri ile orta düzeyde pozitif yönlü ilişkilidir. OYAB bileşik puanları ile hızlı isimlendirme ise orta düzeyde ve negatif yönlü ilişkilidir.

Tablo 9'da görüldüğü gibi bahar dönemi için de okuma bileşik puanı tüm değişkenlerle anlamlı düzeyde ilişkilidir. Okuma bileşik puanı sesbilgisel farkındalık ile orta düzeyde ilişkilidir. Hızlı isimlendirme ile okuma bileşik puanı arasındaki ilişki ise negatif yönlü ve düşük düzeydedir. Okuma bileşik puanının çalışma belleği ve alıcı ve ifade edici sözcük bilgisi ile ilişkisi ise düşük düzeydedir. Anlama bileşik puanı tüm değişkenlerle anlamlı olarak $(p<.01)$ ilişkilidir. Anlama bileşik puanı, çalışma belleği ve ifade edici dil sözcük bilgisi ile orta düzeyde ve pozitif yönlü ilişkiliyken diğer tüm değişkenlerle düşük düzeyde ilişkilidir. Anlama bileşik puanının hızlı isimlendirme testi ile olan ilişkisi ise negatif yönlüdür. Yazma bileşik puanı ile hızlı isimlendirme arasında ilişkili bulunmazken, yazma bileşik puanı diğer tüm değişkenlerle pozitif yönlü ve düşük düzeyde ilişkilidir. Yazma bileşik puanının harf bilgisi olan ilişkisi ise .05 düzeyinde, diğer testlerle ise .01 düzeyinde anlamlıdır. Son olarak OYAB bileşik puanı tüm değişkenlerle ilişkili bulunmuştur. OYAB bileşik puanı sesbilgisel farkındalık ve çalışma belleği ile orta düzeyde pozitif yönlü ilişkilidir. OYAB bileşik puanı hızlı isimlendirme ile düşük ve negatif yönde ilişkiliyken, harf bilgisi ve alıcı-ifade edici sözcük bilgisiyle düşük ve pozitif yönde ilişkilidir.

\section{OYAB'ın Güvenirlik Çalışmalarına iliş̧kin Bulgular}

$O Y A B^{\prime} ı$ güvenirlik analizleri kapsamında iç tutarlık, test tekrar test güvenirliği ile $A$ ve $B$ formlarının eşdeğerlik anlamında güvenirliği incelenmiştir.

\section{OYAB'ın iç Tutarlık Güvenirliği}

OYAB'ın güvenirlik analizleri kapsamında Cronbach alfa katsayısı kullanılarak testlerin tüm sınıf düzeylerinde iç tutarlık güvenirliği hesaplanmıştır. Elde edilen sonuçlar Tablo 10'da verilmiştir.

Tablo 10.

Sınıf Düzeylerinde lç Tutarlıık Katsayıları

\begin{tabular}{lcccccc}
\hline & 1. Sınıf Güz & $\begin{array}{c}\text { 1. Sınıf } \\
\text { Bahar }\end{array}$ & 2. Sınıf Güz & $\begin{array}{c}\text { 2. Sınıf } \\
\text { Bahar }\end{array}$ & 3. Sınıf & 4. Sınıf \\
\hline Testler & $\mathrm{r}$ & $\mathrm{r}$ & $\mathrm{r}$ & $\mathrm{r}$ & $\mathrm{r}$ & $\mathrm{r}$ \\
\hline Okuma Bileşik Puanı & .83 & .81 & .81 & .81 & .81 & .80 \\
\hline Anlama Bileşik Puanı & .85 & .84 & .83 & .84 & .82 & .80 \\
\hline Yazma Bileşik Puanı & .76 & .76 & .74 & .73 & .71 & .67 \\
\hline OYAB Bileşik Puanı & .83 & .79 & .80 & .80 & .80 & .80 \\
\hline
\end{tabular}

Tablo 10 'da görüldüğü gibi dördüncü sınıftaki yazma bileşik puanı dışında tüm sınıf düzeyleri, ve bileşik puanlar için Cronbach alfa katsayıları .70'in üstündedir. Dördüncü sınıftaki yazma bileşik puanının .70'e oldukça yakın bir değer olması nedeniyle kabul edilebilir olduğu düşünülmektedir. Bu sonuçlar OYAB'ın iç tutarlılık güvenirliğinin iyi düzeyde olduğuna dair kanıt oluşturmaktadır. 
İlkokul Çocuklarına Yönelik Geliştirilmiş Okuma Yazma Değerlendirme Bataryasının (OYAB) Geçerlik ve Güvenirlik Çalışması

\section{OYAB'ın Test Tekrar Test Güvenirliği}

OYAB'ın güvenirlik analizleri kapsamında test tekrar test katsayıları incelenmiştir. Bu kapsamda toplam 46 çocuğa ilk uygulamadan iki hafta sonra test-tekrar-test uygulaması yapılmıştır. íki uygulamadan elde edilen test tekrar test korelasyon katsayıları Tablo 11'de verilmiştir.

Tablo 11.

OYAB Bileşik Puanlarına iliş̧kin Test Tekrar Test Katsayıları

\begin{tabular}{ll}
\hline Testler & $r$ \\
\hline Okuma Bileşik Puanı & $.96^{* *}$ \\
\hline Anlama Bileşik Puanı & $.88^{* *}$ \\
\hline Yazma Bileşik Puanı & $.86^{* *}$ \\
\hline OYAB Bileşik Puanı & $.95^{* *}$ \\
\hline${ }^{* *} p<0.01$ &
\end{tabular}

Tablo 11'e göre tüm bileşik puanlarda ve OYAB genelinde iki ölçüm arasındaki korelasyonların .01 düzeyinde anlamlı, pozitif yönlü ve yüksek düzeyde olduğu bulunmuştur.

\section{OYAB'ın A ve B Formlarının Eşdeğerlik Anlamında Güvenirliği}

OYAB'ın eşdeğerlik anlamında güvenirlik düzeyini incelemek amacıyla deneme örneklemi üzerinde A ve B formlarının okuma, anlama, yazma ve toplam puanları arasındaki korelasyonlar Pearson Momentler Çarpımı Korelasyon Katsayısı ile hesaplanmış, sonuçlar Tablo 12' de verilmiştir.

Tablo 12.

A ve B Formlarının Okuma, Anlama, Yazma ve OYAB Bileşik Puanları Arasındaki Korelasyonlar

\begin{tabular}{ll}
\hline & $r$ \\
\hline Okuma & $.95^{* *}$ \\
\hline Anlama & $.91^{* *}$ \\
\hline Yazma & $.82^{* *}$ \\
\hline OYAB & $.96^{* *}$ \\
\hline${ }^{* *} p<0.01$ &
\end{tabular}

Tablo 12'de görüldüğü gibi tüm korelasyonlar 01 düzeyinde anlamlıdır. A ve B formlarının tüm alt alanlar ve OYAB bileşik puanı için korelasyonları .82 ila .96 arasındadır. Bu değerler $A$ ve $B$ formlarının eşdeğerliğini destekleyen bir kanıt sağlamaktadır.

\section{OYAB'ın Kesme Aralıklarının ve Değerlendirme Ölçütlerinin Belirlenmesi}

Çalışma kapsamında son olarak, OYAB'ın tüm test puanları ile okuma, anlama, yazma ve OYAB bileşik puanları için çocukların performanslarını değerlendirmeye yönelik kesme puanları ve aralıkları belirlenmiştir. Tüm test puanlarının ve bileşik puanların normal dağılım göstermesi nedeniyle kesme noktalarının belirlenmesinde ortalama ve standart sapmaya dayalı bağıl değerlendirme ölçütleri kullanılmıştır. Bu kapsamda çocukların performansına yönelik "çok düşük, düşük, orta, yüksek, çok yüksek" olmak üzere beş düzeyli değerlendirme yapılmıştır. Ortalamanın yarım standart sapma altı ve üstü "orta düzey"; bu değerlerin bir standart sapma altı ve üstü "düşük" ve "yüksek" düzeyler; uçlarda kalan kısımlar ise "çok düşük" ve "çok yüksek" düzeyler olarak tanımlanmıştır. Bu tanımlamalar birinci ve ikinci sınıfın güz ve bahar dönemleri ile üçüncü, dördüncü sınıf için ayrı ayrı yapılmıştır. Böylece, çocukların testlerden elde ettikleri puanların sınıf düzeyine ve dönemine uygunluğu ve hangi aralıkta (çok düşük, düşük, orta, yüksek, çok yüksek) yer aldığı ile ilişkili olarak akranlarından ne düzeyde farklılaştığı belirlenebilmektedir.

Bu çalışmada, OYAB'ın geçerliğini belirlemek amacıyla kapsam, yapı, ayırıcılık, boylamsal yordama ve ölçüt geçerliğine yönelik analizler gerçekleştirilirken, güvenirliğini belirlemek amacıyla da iç tutarlık, test tekrar test güvenirlik ve A-B formlarının eşdeğerlik anlamında güvenirliği analizleri 
gerçekleştirilmiştir. Ayrıca tüm sınıf düzeylerinde performansın değerlendirilebilmesine yönelik kesme aralıkları ve değerlendirme ölçütleri belirlenmiştir.

\section{Tartışma ve Sonuç}

Bu çalışmada birinci sınıftan dördüncü sınıfa kadar olan dönemdeki çocukların okuma, okuduğunu anlama ve yazma performanslarının farklı yönleri ile değerlendirilmesine yönelik geliştirilen OYAB'ın geçerlik ve güvenirlik düzeyleri incelenmiş ve sınıf düzeyinde performansa ilişkin kesme aralıkları ve değerlendirme ölçütleri belirlenmiştir. Bu kapsamda yürütülen analizler sonucunda OYAB'ın geçerli ve güvenilir bir araç olarak alanda uygulanabileceği sonucunda ulaşılmıştır.

Kapsam geçerliği uzman görüşleri çerçevesinde sağlanan OYAB'ın yapı geçerliği için açımlayıcı ve doğrulayıcı faktör analizi yapılmıştır. Hem deneme hem de esas uygulamalar ile elde edilen veriler üzerinden yürütülen analizlerde alanyazın temelinde OYAB'a ilişkin oluşturulmuş kuramsal model test edilmiş ve birinci sınıftan dördüncü sınıfa kadar her bir sınıf düzeyinde OYAB'a dahil edilen okuma, anlama ve yazma ile ilişkili değişkenlerin tek boyutlu bir yapı oluşturduğu belirlenmiştir. Bu modelde sadece metin yazma becerilerinin değerlendirmeye alınmadığı birinci sınıf güz dönemi dışında tüm sınıf düzeyleri ve dönemler için çocukların okuma becerileri dört (anlamlı sözcük okuma, anlamsız sözcük okuma, fonetik analiz ve metin okuma) anlama becerileri üç (metin anlama, cümle doğruluğu ve boşluk doldurma) ve yazma becerileri ise beş değişken (dikte, bakarak yazma, metin yazma, menin biçimsel kalitesi, metnin içerik kalitesi) ile tanımlanmıştır. Oluşturulan modelin model veri uyum indeksleri, büyük oranda mükemmele yakın model veri uyumuna ulaşıldığını göstermiştir. Elde edilen bu sonuçlar, OYAB'ın yapı geçerliğinin yüksek olduğunu, alanyazında okuma, okuduğunu anlama ve yazma becerilerini tanımlayan bileşenlerin OYAB'ın yapısı içinde de tanımlanabildiğini ve ilkokul düzeyindeki çocukların okuma yazma becerilerini değerlendirmede etkili bir şekilde kullanılabileceğini göstermektedir. Ek olarak, yapı geçerliği analiz sonuçları OYAB'ın içeriğindeki her bir testten elde edilen puanların ayrı ayrı kullanılabileceği gibi, okuma, anlama ve yazma alanlarında ve OYAB genelinde elde edilecek bileşik puanların da performans değerlendirmede etkili bir şekilde kullanılabileceği ortaya koymaktadır.

Geçerlik analizleri kapsamında ikinci olarak OYAB'ın ayırıclık geçerliği incelenmiş ve bu kapsamda tüm sınıf düzeyleri ve dönemler için test puanları ve bileşik puanlarda alt-üst gruplara dayalı analizler yapılmıştır. Elde edilen bulgular tüm sınıf düzeylerinde ve tüm bileşik puanlarda alt-üst gruplar arasında .001 düzeyinde anlamlı farklar olduğunu, farklılıklara ilişkin etki büyüklüklerinin ise $.56-.71$ arasında oldukça yüksek değerler olduğunu göstermiştir (Green ve Salkind, 2005). Bu sonuçlar, OYAB'ın ayırıcılık geçerliğinin yüksek olduğuna, bataryanın uygulanması ile okuma yazma becerilerinde ortalama altında ve üstünde performansa sahip çocukların etkili bir şekilde ayırılabileceğine işaret etmektedir.

OYAB'ın geçerlik bulgularını desteklemek amacıyla üçüncü olarak OYAB'dan elde edilen puanların boylamsal yordayıcılığı incelenmiştir. Buna göre, çocukların birinci sınıfın güz ve bahar dönemlerindeki performanslarının ikinci sınıf güz ve bahar dönemlerindeki OYAB performanslarını ne düzeyde açıklayabildiği analiz edilmiştir. Elde edilen sonuçlar OYAB'ın boylamsal yordayıcılığının güçlü olduğunu, çocukların birinci sınıf güz dönemindeki performanslarının ikinci sınıf güz ve bahar dönemlerindeki performanslarını .36 ve .32 düzeyinde açıkladığını, birinci sınıf bahar dönemindeki performanslarının ise ikinci sınıf güz ve bahar dönemlerindeki performanslarını .59 ve .48 düzeyinde açıkladığını göstermiştir. Bu sonuçlar, okuma yazma performansının yordayıcılığına ilişkin yürütülmüş önceki çalışmaların sonuçları uyumludur (Ball, O'Connor, 2016; McCoach, O'Connell, Reis ve Levitt, 2006; Nordström, Jacobson ve Söderberg, 2016; Phillips, Norris, Osmond ve Maynard, 2002). Birinci sınıfın ilk dönemi çocukların okumayı yazmayı öğrenme sürecidir ve bu nedenle çocukların performanslarında önemli düzeyde bireysel farklılıklar görülebilmektedirler (Afflerbach, 2005). Buna karşın, birinci sınıfın ikinci döneminde ilk okuma yazma öğretim süreci büyük ölçüde tamamlanmış olduğundan çocukların performansları daha yerleşik hale gelmektedir (McCoach ve diğ., 2006; Öney ve Durgunoğlu, 1997; Parrila, Aunola, Leskinen, Nurmi ve Kirby, 2005). Bu çerçevede çocukların OYAB 
puanlarının birinci sınıfın her iki döneminde de sonraki OYAB performansına ilişkin güçlü yordayıcılık göstermesine rağmen, bahar dönemindeki performanslarının daha yüksek yordayıcılık göstermesi beklendik bir bulgu olarak değerlendirilmiştir.

Geçerlik analizleri kapsamında son olarak, OYAB'ın ölçüt geçerliği okuma yazma becerilerinin gelişiminde etkili olduğu belirtilen sesbilgisel farkındalık, çalışma belleği, hızı isimlendirme ve dil performansları ile ilişkili olarak incelenmiştir. Elde edilen sonuçlar OYAB puanlarının birinci sınıfta tüm değişkenlerle, ikinci sınıfta ise harf bilgisi dışındaki tüm değişkenlerle anlamlı olarak ilişkili olduğunu göstermiştir. Birinci sınıf güz döneminde OYAB puanları en çok harf bilgisi ve sesbilgisel farkındalık ile ilişkili iken, bahar döneminde sesbilgisel farkındalık, hızlı isimlendirme ve çalışma belleği ile ilişkilidir. íkinci sınıfta ise OYAB puanlarının harf bilgisi dışında diğer değişkenler ile ilişkilerinin ilk yılda olduğundan daha yüksek olduğu belirlenmiştir. Bu sonuçlar da önceki araştırma sonuçları ile tutarlıdır (Chow, McBride-Chang ve Burgess, 2005; Kirby, Desrochers, Roth ve Lai, 2008; McCoach ve diğ., 2006). Sesbilgisel farkındalık, hızlı isimlendirme ve çalışma belleği alanyazında okuma becerilerindeki gelişimi açıklamaya yönelik oluşturulmuş ve yaygın olarak araştırılmış sesbilgisel işlemleme yaklaşımının içeriğindeki becerilerdir (Chow ve diğ., 2005; Ergül ve diğ., 2020; Hoien-Tengesdal ve Tonnessen, 2011; Knoop-van, Campen, Segers ve Verhoeven, 2018; Wagner, Torgesen ve Rashotte, 1994). Dolayısıyla ilkokulun ilk yıllarında OYAB puanlarının en yüksek düzeyde bu beceriler ile ilişkili olduğunun bulunması beklendik bir bulgu iken, bu ilişkinin aynı zamanda OYAB'ın geçerliğine de önemli bir katkı sunduğunu söylemek mümkündür.

OYAB'ın güvenirlik analizler kapsamında ise iç tutarlık, test-tekrar-test güvenirliği ve $A$ ve $B$ formlarının eşdeğerlik anlamında güvenirliği incelenmiştir. Analiz sonuçları iç tutarlık için Cronbach alfa katsayılarının .67 ile .85 arasında değiştiğini, test tekrar test güvenirliğinin .86-.96 arasında olduğunu ve $A$ ve $B$ formlarının tüm alt alanlar ve OYAB bileşik puanı için korelasyonlarının .82 ile .96 arasında değiştiğini göstermiştir. Bu sonuçlar, OYAB'ın güvenirliğinin yüksek olduğuna işaret etmektedir. Bu bağlamda çalışmanın bulguları okuma yazma becerilerini değerlendirmeye yönelik geliştirilen ölçme araçlarına ilişkin güvenirlik bulguları ile benzerlik göstermektedir (Hoover vd., 2003; Hosp, Suchey ve Burns, 2014; Kerbow ve Bryk, 2005; Lipson ve Wixson, 2009; Northwest Evaluation Association, 2011).

Son olarak, tüm testlerde ve bileşik puanlarda çocukların performanslarını değerlendirmeye esas kesme puanları ve aralıkları belirlenerek performansa yönelik "çok düşük, düşük, orta, yüksek, çok yüksek" değerlendirmeleri yapılmıştır. Ortalama ve standart sapmaya dayalı bağıl değerlendirme ölçütleri kullanılarak yürütülen analizler sonucunda her bir sınıf düzeyi için ve birinci ve ikinci sınıfta ise her bir dönem için okuma, anlama ve yazma testlerine ve bileşik puanlarına yönelik kesme puanları ve değerlendirme düzeyleri oluşturulmuştur (Lipson ve Wixson, 2009). Bu çalışma ile çocukların performanslarının sınıf düzeyine ve dönemine uygun olup olmadığının, akranlarından ne düzeyde farklılık gösterdiğinin ve bu kapsamda hangi becerilerde güçlük yaşadığının ve desteğe gereksinim duyduğunun belirlenmesi mümkün olabilecektir (Afflerbach, 2005; Nelson, Van Norman ve VanDerHeyden, 2017).

Sonuç olarak, çalışmadan elde edilen bulgular ışığında OYAB'ın birinci sınıftan dördüncü sınıfa kadar olan dönemdeki çocukların okuma, okuduğunu anlama ve yazma performanslarının farklı yönleri ile değerlendirilmesinde geçerli ve güvenilir bir ölçme aracı olduğu ve ülkemizdeki alanyazına ve uygulamalara önemli katkılar sağlayacağı düşünülmektedir. Okuma yazma becerilerinin çocukların akademik başarılarının temelini oluşturması ve bu bağlamda yaşamdaki başarılarının da çok önemi bir belirleyicisi olması nedeniyle (Kirby ve diğ., 2008; Nordström, Jacobson ve Söderberg, 2016) özellikle ilkokul dönemindeki çocukların bu alanlarda gösterdiği performanslarının OYAB ile değerlendirilerek beklenen düzeyde performans gösterip göstermediklerinin ve bir müdahaleye gereksinim duyup duymadıklarının belirlenmesi mümkün olacaktır. Ek olarak, OYAB ile okuma, okuduğunu anlama ve yazma becerileri farklı görevler içeren testlerle ve farklı yönleriyle değerlendirilebildiğinden çocukların hangi alanlarda ne tür problemler yaşadıklarının belirlenebileceği ve buna göre müdahale programının içeriğinin daha etkili bir şekilde planlanabileceği düşünülmektedir. Ayrıca, okuma, okuduğunu anlama ve yazma alanlarında yaşanan sınırlııkların özellikle öğrenme güçlükleri ile tanılanmanın temel nedeni 
olduğu göz önünde bulundurulduğunda (Scarborough, 2002; Stanovich, 2009; Vellutino, Fletcher, Snowling ve Scanlon, 2004) bu değerlendirme bataryası kullanılarak akademik başarısızlık ve öğrenme güçlüğü açısından risk grubunda değerlendirilen çocukların erken dönemde belirlenmesi ve oluşturulacak müdahale programları ile olası başarısızlık risklerinin en aza indirilmesi mümkün olabilecektir. Bu açıdan, ülkemizde çocukların okuma, okuduğunu anlama ve yazma performanslarını değerlendirmeye yönelik standardizasyonu yapılmış araçların ve ilgili çalışmaların sınırlı olduğu göz önünde bulundurulduğunda, bu çalışma kapsamında geçerlik ve güvenirlik analizleri yapılan OYAB'ın yeni yapılacak çalışmalara temel oluşturacağı ve öncülük edeceği öngörülmektedir. Son olarak, OYAB testlerinin süre temelli olarak uygulanmasının zaman açısından uygulama kolaylığı sağlayacağı ve çocukların performanslarının doğruluk ve hız açısından iki yönlü değerlendirilmesine olanak tanıyarak performansa ilişkin daha güçlü göstergeler sunacağı düşünülmektedir (Christ, Silberglitt, Yeo ve Cormier, 2010; Deno, Fuchs, Marston ve Shinn, 2001; Fuchs, Fuchs, Hamlett, Walz ve Germann, 1993; Hosp, Suchey ve Burns, 2014).

\section{Sınırlılıklar ve Öneriler}

Analizler sonucunda OYAB'ın geçerlik ve güvenirliğinin yüksek olduğu yönünde çok sayıda kanıt elde edilmesine rağmen sonuçlar değerlendirilirken çalışmanın göz önünde bulundurulması gereken bazı sınırlılıkları bulunmaktadır. Illk olarak, OYAB'ın burada sunulan geçerlik ve güvenirlik verileri sadece Ankara ili merkezindeki ilkokullara devam eden ve tipik gelişim gösteren çocuklar ile sınırlıdır. Bu açıdan, geçerlik ve güvenirlik verilerinin güçlendirilmesi amacıyla OYAB testlerinin farklı illerden oluşturulmuş daha büyük ve farklı özelliklerdeki çocukları (özel gereksinimli çocuklar) içeren örneklem gruplarına uygulanması ve analizlerin tekrarlanması önerilmektedir. İkincisi ise çalışmada OYAB'ın ölçüt geçerliği, OYAB puanları ile alanyazında okuma yazma becerilerinin gelişimi açısından önemli olduğu gösterilen sesbilgisel farkındalık, çalışma belleği, hızlı isimlendirme ve dil performansları arasındaki ilişkiler incelenerek belirlenmiştir. Oysa ölçüt geçerliğinin okuma yazma becerilerini değerlendirmeye yönelik geçerli ve güvenirliği sağlanmış başka bir araçtan elde edilen puanlarla ilişkili olarak incelenmesi önemlidir. Bu nedenle, ileri araştırmalarda OYAB'ın ölçüt geçerliğinin yeni bulgularla desteklenmesinin önemli olduğu düşünülmektedir.

\section{Araştırma ve Yayın Etiği}

Bu çalışmada "Yükseköğretim Kurumları Bilimsel Araştırma ve Yayın Etiği Yönergesi" kapsamında uyulması belirtilen tüm kurallara uyulmuştur. Yönergenin ikinci bölümü olan "Bilimsel Araştırma ve Yayın Etiğine Aykırı Eylemler" başlığı altında belirtilen eylemlerden hiçbiri gerçekleştirilmemiştir.

\section{Etik Kurul İzni}

Kurul adı= Ankara Üniversitesi Etik Kurulu

Karar tarihi $=13 / 3 / 2014$

Belge sayı numarası $=1110$

\section{Yazarların Katkı Oranı}

Makaleye 1. yazar $\% 30$, 2. yazar $\% 20$, 3. yazar $\% 20$, 4. yazar $\% 20$ ve 5 . yazar $\% 10$ düzeyinde katkı sunmuştur.

\section{Destek ve Teşekkür}

Bu çalışma TÜBITAK tarafından desteklenen 215K027 nolu proje kapsamında yürütülmüştür. Sağladığı destek nedeniyle TÜBiTAK'a teşekkür ederiz. 


\section{Kaynaklar}

Afflerbach, P. (2005). National Reading Conference policy brief high stakes testing and reading assessment executive summary. Journal of Literacy Research, 37(2), 151-162.

Afonso, O., Connelly, V., ve Barnett, A. L. (2019). Struggling with writing: An examination of writing difficulties in specific language impairment, developmental dyslexia and developmental coordination disorder. C.Perret ve T. Olive (Eds.), Spelling and Writing Words: Theoretical and Methodological Advances (pp. 112-127). Brill.

Akyol, H. (2015). Türkçe ilk okuma yazma öğretimi. Ankara: Pegem Akademi Yayıncılık.

Akyol, H., ve Sever, E. (2018). Okuma yazma güçlüğü ve bir eylem araştırması: İkinci sınıf örneği. Hacettepe Üniversitesi Eğitim Fakültesi Dergisi, 34(3), 685-707.

Babür, N., Haznedar, B., Erçetin, G., Özerman, D., ve Çekerek, E. (2011). Türkçe' de Kelime Okuma Bilgisi Testi'nin geliştirmesi. (КОВіт). Boğaziçi Üniversitesi Eğitim Dergisi, 28(2), 1-21.

Ball, C. R., ve O'Connor, E. (2016). Predictive utility and classification accuracy of oral reading fluency and the measures of academic progress for the Wisconsin knowledge and concepts exam. Assessment for Effective Intervention, 41, 195-208.

Boscolo, P. (2008). Writing in primary school. C. Bazermen (Ed.), Handbook of research on writing: History, society, school, individual, text (pp.293-309). L. Erlbaum Associates.

Breznitz, Z. (2005). Fluency in reading: Synchronization of processes. Lawrence Erlbaum Associates.

Burns, S. M., Kidd, J. K., ve Genarro, T. (2010). Writing: Underutilized for young children with disabilities? Scruggs, T. E. ve Mastropieri, M. A. (Eds.) Literacy and Learning (pp. 175204). Emerald Group Publishing Limited.

Caglar-Ryeng, Ö., Eklund, K., ve Nergard-Nissen, T. (2019). Lexical and grammatical development in children at family risk of dyslexia from early childhood to school entry: A cross-lagged analysis. Journal of Child Language, 46(6), 1102-1126.

Chard, D. J., Vaughn, S., ve Tyler, B. (2002). A synthesis of research on effective interventions for building reading fluency with elementary students with learning disabilities. Journal of Learning Disabilities, 35(5), 386-406.

Chow, B. W. Y., McBride-Chang, C., ve Burgess, S. (2005). Phonological processing skills and early reading abilities in Hong Kong Chinese kindergarteners learning to read English as a second language. Journal of Educational Psychology, 97(1), 81-87.

Christ, T. J., Silberglitt, B., Yeo, S., ve Cormier, D. (2010). Curriculum-based measurement of oral reading: An evaluation of growth rates and seasonal effects among students served in general and special education. School Psychology Review, 39, 447-462.

Clarke, P. J., Truelove, E., Hulme, C., ve Snowling, M. (2014). Developing reading comprehension. Hoboken: John Wiley ve Sons, Ltd.

Cunningham, A. E., ve Stanovich, K. E. (1997). Early reading acquisition and its relation to reading experience and ability 10 years later. Developmental Psychology, 33(6), 934-945.

Deno, S. L., Fuchs, L. S., Marston, D., ve Shinn, J. (2001). Using curriculum-based measurements to establish growth standards for students with learning disabilities. School Psychology Review, 30, 507-524.

Erden, G., ve Çelik, C. (2019). Sesli okuma becerisi ve okuduğunu anlama testinin psikometrik özelliklerinin incelenmesi: Geçerlik ve güvenirlik çalışması. Nesne, 7(14), 1-18.

Ergül, C. (2012). Okumada güçlük yaşayan öğrencilerin okuma performanslarının öğrenme güçlüğü riski açısından değerlendirilmesi. Kuram ve Uygulamada Eğitim Bilimleri, 12(3), 2033-2057.

Ergül, C., Ökcün-Akçamuş, M. Ç., Akoğlu, G., Bahap Kudret, Z., Kılıç Tülü B., Demir, E., ve Okşak F. E. (2020). Türkçe konuşan çocuklarda fonolojik işlemleme becerileri ilk okuma performansını yorduyor mu? Boylamsal sonuçlar. Hacettepe Üniversitesi Eğitim Fakültesi Dergisi, Doi: 10.16986/HUJE.2020062765

Fuchs, L. S., Fuchs, D., Hamlett, C. L., Walz, L., ve Germann, G. (1993). Formative evaluation of academic progress: How much growth can we expect? School Psychology Review, 22, 27-48. 
Goldsworthy, C. L. (2003). Developmental reading disabilities: A language based treatment approach. Thomson Learning, Inc.

Graham, C. R. (2006). Blended learning systems. C. J. Bonk ve C. R. Graham (Eds.), The Handbook of blended learning: Global perspectives, local designs, (pp. 3-21). Pfeiffer.

Graham, S. (2010). Want to improve children's writing? Education Digest, 76(1), 49-55.

Graham, S., ve Harris, K. R. (2005). Improving the writing performance of young struggling writers: Theoretical and programmatic research from the center on accelerating student learning. Journal of Special Education, 39(1), 19-33.

Green, S. B., ve Salkind, N. J. (2005). Using SPSS for Windows and Macintosh: Analyzing and understanding data (4th ed.). Upper Saddle River, USA: Pearson.

Hoien-Tengesdal, I., ve Tonnessen, F. (2011). The relationship between phonological skills and word reading. Scandinavian Journal of Psychology, 52, 93-103.

Hoover, H., Dunbar, D., Frisbie, D., Oberley, K., Bray, G., Naylor, R., et al. (2003). The lowa Tests of Basic Skills. Rolling Meadows, IL: Riverside Publishing

Hoover, W. A., ve Gough, P. B. (1990). The simple view of reading. Reading and Writing, 2(2), 127-160.

Hosp, J. L., Suchey, N., ve Burns, M. (2014). Reading assessment: Reading fluency, reading fluently, and comprehension. School Psychology Review, 43, 59-68.

Hougen, M. (2014). Evidence-based reading instruction for adolescents, grades 6-12 (Document No. IC13). Erişim adresi: http://ceedar.education.ufl.edu/tools/innovation-configurations

Hudson, R. F., Lane, H. B., ve Pullen, P. C. (2005). Reading fluency assessment and instruction: What, why, and how? The Reading Teacher, 58(8), 702-714.

İmer, K., Kocaman, A., ve Özsoy, A. S. (2011). Dilbilim sözlüğü. İstanbul: Boğaziçi Üniversitesi Yayınevi.

Katzir, T., Kim, K., Wolf, M., O’Brien, B., Kennedy, B., Lovett, M., ve Morris, R. (2006). Reading fluency: Whole is more than parts. Annals of Dyslexia, 56(1), 51-82.

Kerbow, D., ve Bryk, A. (2005). STEP literacy assessment: Technical report of validity and reliability. Erişim adresi: https://docplayer.net/9212668-Step-literacy-assessment-technical-report-ofvalidity-and-reliability.html

Kirby, J. R., Desrochers, A., Roth, L., ve Lai, S. S. (2008). Longitudinal predictors of word reading development. Canadian Psychology, 49(2), 103-110.

Knoop-van Campen, C. A., Segers, E., ve Verhoeven, L. (2018). How phonological awareness mediates the relation between working memory and word reading efficiency in children with dyslexia. Dyslexia, 24(2), 156-169.

Kuhn, M. (2004). Helping students become accurate, expressive readers: Fluency instruction for small groups. The Reading Teacher, 58(4), 338-344.

Kuhn, M. R., Schwanenflugel, P. J., ve Meisinger, E. B. (2010). Aligning theory and assessment of reading fluency: automaticity, prosody, and definitions of fluency. Reading Research Quarterly, 45(2), 230-251.

Kuhn, M. R., Schwanenflugel, P. J., Morris, R. D., Morrow, L. M., Woo, D. G., Meisinger, E. B. ve ark. (2006). Teaching children to become fluent and automatic readers. Journal of Literacy Research, 38(4), 357-387.

Lambert, M. (2007). A guide to reading fluency and the assessment of specific learning disabilities in the individuals with disabilities education improvement act of 2004. Wisconsin Department of Public Instruction. Erişim adresi: https://dpi.wi.gov/sites/default/files/imce/sped/pdf/reading-fluency-draft.pdf

Lipson M. Y., ve Wixson, K. K. (2009). Assessment and instruction of reading and writing difficulties (4th ed.). New York: Pearson.

Logan, G. D. (1997). Automaticity and reading: Perspectives from the instance theory of automatization. Reading ve Writing Quarterly, 13(2), 123-146. 
Maclean, M. J., Taylor, C. L., ve O'Donnell, M. (2016). Pre-existing adversity, level of child protection involvement, and school attendance predict educational outcomes in a longitudinal study. Child Abuse ve Neglect, 51, 120-131.

McCoach, D. B., O'Connell, A., Reis, S., ve Levitt, H. (2006). Growing readers: A hierarchical linear model of children's reading growth during the first 2 years of school. Journal of Educational Psychology, 98, 14-98

Meisinger, E. B., Bloom, J., ve Hynd, G. W. (2010). Reading fluency: Implications for the assessment of children with reading Disabilities. Annals of Dyslexia, 60, 1-17.

Melekoğlu, M. A., Erden, H. G., ve Çakıroğlu, O. (2019). Development of the Oral Reading Skills and Comprehension Test-II (SOBAT ${ }^{\circledR}-$ II) for assessment of Turkish children with specific learning disabilities: Pilot study results. Journal of Educational Issues, 5(2), 135-149.

Nandhini, K., ve Balasundaram, S. R. (2011, July). Improving readability of dyslexic learners through document summarization. IEEE International Conference (pp. 246-249). Chennai, Tamil Nadu, India.

National Assessment of Educational Progress, (2013). Nation's report card. National Center for Education Statistics, Institute of Education Sciences, U.S. Department of Education. Erişim adresi:

https://nces.ed.gov/nationsreportcard/subject/publications/main2013/pdf/2014451.pdf

Nelson, P. M., Van Norman, E. R., ve VanDerHeyden, A. (2017). Reduce, reuse, recycle: The longitudinal value of local cut scores using state test data. Journal of Psychoeducational Assessment, 35, 683-694.

Nordström, T., Jacobson, C., ve Söderberg, P. (2016). Early word decoding ability as a longitudinal predictor of academic performance. European Journal of Psychology of Education, 31, 175191.

Northwest Evaluation Association (2011). Technical manual for measures of academic progress and measures of academic progress for primary grades. Erişim adresi: https://www.richland2.org/RichlandDistrict/media/Richland

District/AdvancED/Standard\%205/5.1/5-1-NWEA-Technical-Manual-for-MAP-and-MPG.pdf

Oakhill, J., Cain, K., ve Elbro, C. (2019). Reading comprehension and reading comprehension difficulties. D. Kilpatrick, R. Joshi, W. Malatesha, ve K. Richard (Eds.), Reading development and difficulties (pp. 83-115). Springer.

Ou, S.-R., ve Reynolds, A. J. (2008). Predictors of educational attainment in the Chicago longitudinal study. School Psychology Quarterly, 23(2), 199-229.

Öney, B., ve Durgunoğlu, A. Y. (1997). Learning to read in Turkish: A phonologically transparent orthography. Applied Psycholinguistics, 18(1), 1-15.

Parrila, R., Aunola, K., Leskinen, E., Nurmi, J. E., ve Kirby, J. (2005). Development of individual differences in reading: Results from longitudinal studies in English and Finnish. Journal of Educational Psychology, 97, 299-319.

Peng, P., Fuchs, D., Fuchs, L., Elleman, A.M., Kearns, D.M., Gilbert, J., ... Patton, S. (2019). A longitudinal analysis of the trajectories and predictors of word reading and reading comprehension development among at-risk readers. Journal of Learning Disabilities, 52(3), 195-208.

Perfetti, C. A. (1985). Reading ability. Oxford University Press.

Perfetti, C. A. (2010). Decoding, vocabulary, and comprehension. M. G. McKeown ve L. Kucan (E), Bringing reading research to life (pp. 291-303). Guilford Press.

Perfetti, C., Landi, N., ve Oakhill, J. (2005) The acquisition of reading comprehension skill. M. J. Snowling ve C. Hulme (Eds.), The science of reading (pp. 227-247). Blackwell Publishing.

Phillips, L. M., Norris, S. P., Osmond, W. C., ve Maynard, A. M. (2002). Relative reading achievement: A longitudinal study of 187 children from first through sixth grade. Journal of Educational Psychology, 94, 3-13. 
Rasinski, T. (2006). Reading fluency instruction: Moving beyond accuracy, automaticity, and prosody. The Reading Teacher, 59(7), 704-706.

Richek, M. A., Caldwell J. S., Jennings, J. H., ve Lerner, J. W. (2002). Reading problems: Assessment and teaching strategies. Boston: Allyn ve Bacon.

Saddler, B. (2006). Increasing story-writing ability through self-regulated strategy development: Effects on young writers with learning disabilities. Learning Disability Quarterly, 29(4), 291-305.

Scales, P. C., Benson, P. L., Roehlkepartain, E. C., Sesma Jr, A., ve van Dulmen, M. (2006). The role of developmental assets in predicting academic achievement: A longitudinal study. Journal of Adolescence, 29(5), 691-708.

Scanlon, D. M., Anderson, K. L., ve Sweeney, J. M., (2010). Early inventions for reading difficulties. Guilford Press.

Scarborough, H. S. (2002). Connecting early language and literacy to later reading (dis) abilities: Evidence, theory, and practice. In S. B. Neuman ve D. K. Dickinson (Eds.), Handbook of early literacy research (pp. 97-110). New York, NY: Guilford Press.

Seçkin-Yılmaz, Ş., ve Baydık, B. (2017). Okuma performansı düşük olan ve olmayan ilkokul öğrencilerinin okuma akıcılıkları. Elementary Education Online, 16(4), 1652-1671.

Snowling, M. J., Duff, F. J., Nash, H. M., ve Hulme, C. (2016). Language profiles and literacy outcomes of children with resolving, emerging, or persisting language impairments. Journal of Child Psychology and Psychiatry, 57(12), 1360-1369.

Snowling, M. J., Lervag, A., Nash, H. M., ve Hulme, C. (2019). Longitudinal relationships between speech perception, phonological skills and reading in children at high-risk of dyslexia. Developmental Science, 22(1), 1272-1289.

Stanovich, K. E. (1991). Discrepancy definitions of reading disability: Has intelligence led us astray?. Reading Research Quarterly, 26(1), 7-29.

Stanovich, K. E. (2009). Matthew effects in reading: Some consequences of individual differences in the acquisition of literacy. Journal of Education, 189, 23-55.

Tannenbaum, K. R., Torgesen, J. K., ve Wagner, R. K. (2009). Relationships between word knowledge and reading comprehension in third-grade children. Scientific Studies of Reading, 10(4), 381398.

Uzunkol, E. (2013). Akıcı okuma sürecinde karşılaşılan sorunların tespiti ve giderilmesine yönelik bir durum çalışması. Mersin University Journal of the Faculty of Education, 9(1), 70-83.

Valdez, C. R., Lambert, S. F., ve lalongo, N. S. (2011). Identifying patterns of early risk for mental health and academic problems in adolescence: A longitudinal study of urban youth. Child Psychiatry ve Human Development, 42(5), 521-538.

Wagner, R. K., Torgesen, J. K., ve Rashotte, C. A. (1994). Development of reading-related phonological processing abilities: New evidence of bidirectional causality from a latent variable longitudinal study. Developmental Psychology, 30(1), 73-87.

Westwood, P. S. (2008). What teachers need to know about reading and writing difficulties. ACER Press.

Willoughby, M. T., Wylie, A. C., ve Little, M. H. (2019). Testing longitudinal associations between executive function and academic achievement. Developmental Psychology, 55(4), 767-779.

Yuill, N., Oakhill, J., ve Oakhill, O. J. (1991). Children's problems in text comprehension: An experimental investigation. Cambridge University Press.

\section{Extended Abstract}

Introduction

Reading and writing are the most fundamental skills that are aimed to be taught to children at school. Studies have shown that achievement in literacy skills is one of the strongest variables that predict later academic achievement. However, individual differences are frequently observed in the acquisition and development of literacy skills, and the literacy achievement of children who are at the 
same grade level and who have gone through the same formal education process can differ significantly. There are many studies showing that the failure in literacy skills continue consistently throughout school life and turn into a general academic failure and a learning disability diagnosis. Therefore, it is very important to assess reading, reading comprehension and writing skills comprehensively and determine the difficulties experienced by children. Literacy Assessment Battery (LAB) was developed from this point of view to assess the reading, reading comprehension, and writing skills of the children attending primary school and to determine whether they have difficulties in any of these areas. In this study, the validity and reliability of $L A B$ were analyzed and the cut-off points and evaluation criteria for each grade level were established.

\section{Method}

The participants of the study consisted of 1177 children attending first, second, third and fourth grades in primary schools (public and private) located in Ankara and affiliated to the Ministry of National Education. This research was carried out in two stages as a trial and a main study. Accordingly, 252 of the participants took part in the trial study $(F=123, M=129)$ and 925 took part in the main study ( $F=476, M=449)$. In the study, the SES Index Parent Information Form was used to determine the SES of the families. Children's literacy skills were assessed using LAB which is a test battery developed by the researchers of this study. LAB includes four tests to assess reading skills (Word Recognition Test, Word Decoding Test, Phonetic Analysis Test, and Passage Reading Test), three tests to assess comprehension skills (Semantic Processing Test, Cloze Test and Passage Comprehension Test), and three tests to assess writing skills (Spelling Test, Copying Test and Writing Expression Test). Most of these tests are timed tests in which the number of correctly read/written words or items answered is determined at a certain period (eg., 1 minute, 90 seconds). Each test has parallel forms as $A$ and $B$ and assessments are carried out individually.

In the analysis of the data, firstly the descriptive statistics of the data were examined and then analysis of the test the validity and reliability of LAB was performed. Content validity, structure validity, discrimination validity, longitudinal predictive, and criterion validity analyzes were completed to determine the validity of the LAB. Also, internal consistency coefficient, test-retest, and equivelance of $A-B$ forms were examined for the reliability analyses. Finally, cut-off intervals for assessing the performance of children for each grade level and evaluation criteria for these intervals were determined.

\section{Result and Discussion}

In the analyses, first, the content validity of LAB was examined by asking eight field experts to evaluate the suitability of the test items to grade levels, the ordering of the items, and the equivalence of $A$ and $B$ forms. In these evaluations, experts were expected to grade all tests and test items as $1=$ appropriate; 2 = should be improved; $3=$ not appropriate. Results showed that experts' average scores were between 1.00-1.25 for all the tests indicating that $L A B$ had content validity. Second, in order to examine the construct validity of the $L A B$, a theoretical model was established based on the relevant literature and model-data fit was tested with CFA. As a result of the analysis, it has been found that the $\mathrm{X} 2$ values for model data fit were significant in all models created for all grade levels and the X2/df ratios were below 5 . These values indicated the perfect model-data fit. The RMSEA and RMR values for the error terms were between .03 and .10 for each grade level revealing that there was an acceptable level of model-data fit. Other goodness of fit indices was above .90 which also showed LAB had the near-perfect model-data fit. Third, the discriminant validity of LAB was examined by comparing upper-lower groups' LAB scores. Results showed that there were significant differences at .001 level between the groups in all composite scores for each grade level with big effect sizes (.56-.71 for 1st2nd grades; .63-.67 for 3rd-4th grades). Fourth, the longitudinal predictive validity of LAB was examined to see whether reading, comprehension and writing composite scores in first grade predicted LAB total composite scores in the fall and spring semesters of second grade. Results revealed 
that reading and reading comprehension composite scores in the fall of first grade and reading, reading comprehension, and writing composite scores in the spring of first grade significantly predicted the $L A B$ total composite score in both semesters of second-grade which altogether constituted evidence for the longitudinal predictive validity of LAB. Fifth, in order to examine the criterion validity of $L A B$, the relationships between children's reading, reading comprehension, writing, and LAB total composite scores and children's scores in the variables of letter knowledge, phonological awareness, working memory, rapid automatized naming, language, and vocabulary, which are often found related with the literacy skills in the literature, were computed. Result of the analysis showed that there was a significant relationship between the scores revealing evidence for the criterion validity.

Within the scope of the reliability analysis of the $L A B$, the internal consistency of the tests at all grade levels was examined and found that the Cronbach alpha coefficients for all composite scores were above .70 at all grade levels, except for the writing composite score in the fourth grade. It was observed that the writing composite score in the fourth grade was quite close to .70 and this value was considered to be acceptable. These results constituted evidence for the internal consistency reliability of LAB. Test-retest coefficients were also examined and it was found that the correlations between the two assessments were significant at the level of .01 in all composite scores of $L A B$. For the equivalence reliability of LAB's $A$ and $B$ forms, the correlations between all composite scores in $A$ and $B$ forms were computed and found that the correlation between the two forms was between .82 and .96 .

Finally, in order to evaluate children's performance, the cut-off scores/intervals and evaluation criteria (very low, low, medium, high, very high) were determined in all LAB tests and composite scores at all grade levels. Thus, it can be determined whether children's performance is appropriate for their grade level and to what extent the children's test scores differ from their peers.

In conclusion, in the light of the findings obtained from the study, it is thought that LAB is a valid and a reliable tool to assess the reading, reading comprehension and writing performances of children from the first grade to the fourth grade with different aspects and will make significant contributions to the literature and practices in our country. 